\title{
Characterisation of palytoxin from an undescribed Palythoa (Anthozoa: Zoantharia: Sphenopidae) with significant in vitro cytotoxic effects on cancer cells at picomolar doses
}

Ludovic Sawelew ${ }^{1,4}$, Frédéric Gault ${ }^{4}$, Christopher Nuccio ${ }^{3}$, Yvan Perez $^{2,4 \#}$, Jean Lorquin ${ }^{1 \#}$

${ }^{1}$ Mediterranean Institute of Oceanography (MIO) UM 110, Aix-Marseille Université, CNRS, Université de Toulon, IRD, Marseille, France

${ }^{2}$ Institut Méditerranéen de Biodiversité et d'Ecologie marine et continentale UMR 7263, AixMarseille Université, Avignon Université, CNRS, IRD, Marseille, France

${ }^{3}$ Centre de Recherche en Oncologie biologique et Oncopharmacologie (CRO2) INSERM S911, Aix-Marseille Université, CNRS, Marseille, France

${ }^{4}$ Coral Biome SAS, Zone Luminy Entreprises, 163 avenue de Luminy, 13288 Marseille cedex 9, France

\# Equal contributors

Correspondence to:

Jean Lorquin, Phone: (+33) 491828 575; E-mail: jean.lorquin@univ-amu.fr

Frédéric Gault, Phone: (+33) 491828 490; Email: info-pharma@coralbiome.com

Keywords: palytoxin, Palythoa, Symbiodinium, cytotoxicity, antitumor activity, MALDIimaging mass spectrometry.

\begin{abstract}
Palytoxin (PITX), a large polyhydroxylated compound, is among the most potent non-peptide toxin in marine organisms known so far. The literature emphasizes the sodium/potassium pump (NaK) as the privileged target for PITX when exerting its toxic effects. In this study, we focused on an undescribed species (Palythoa sp. Pc001), a coral species belonging to the genus Palythoa routinely cultivated in aquariums. We demonstrated that this species contains one of the highest yields of pure PITX production ever found, $2.22 \pm 0.41 \mathrm{mg}$ PITX per gram of wet Palythoa. Using molecular data combined with external morphology, we identified Palythoa sp. Pc001 as the sister species to Palythoa aff. clavata. Further, the clade of a symbiotic Symbiodinium sp. was characterised by DNA barcoding and pigment content.
\end{abstract}


Molecular data showed that Palythoa sp. Pc001 contains 'generalist' Symbiodinium belonging to clade C. This paper also describes for the first time the localisation of PITX and Symbiodinium cells in tissues of a highly toxic Palythoa species. PITX toxicity was assayed on 72 h-cultured murine and human cancer cells versus the normal human dermal fibroblast (NHDF; PC C12300) cell line. Using MTT colorimetric assay and quantitative videomicroscopy, our results showed much higher in vitro cytotoxic activity on cancer cells $\left(\mathrm{IC}_{50} 0.54 \pm 0.05 \times 10^{-12} \mathrm{M}\right)$ than on non-cancerous ones $\left(\mathrm{IC}_{50}>1 \times 10^{-6} \mathrm{M}\right)$. Such a strong differential effect has never been reported with respect to the most potent NaK ligands (cardiac glycosides) described so far. Moreover, PITX displayed similar in vitro growth inhibitory activity in rodent and human cancer cells, although the $\mathrm{NaK}$ in rodents displays a double mutation in the $\alpha 1$-subunit that usually decreases the sensitivity to others cardiac glycosides like ouabain, when compared to human cells. This work demonstrates, first, that picomolar concentrations of PITX have significant higher cytotoxic effects on cancer cells than on non-cancerous ones, and secondly, that this in vitro antitumor effect would not be entirely relied onto its canonical targeting to the NaK $\alpha$-subunit. Thus, PITX ranks amongst highly potent anti-cancer drugs as it targets cancers while potentially minimizing the drug's side effects on healthy cells.

\section{Introduction}

Many organisms such as animals, plants and bacteria are known to secrete poisonous substances in their environment to protect themselves from aggressors. These toxins may also be very useful in cancer therapy due to their high cell-killing potency [1-3]. PITX, one of the most toxic natural compounds known to date, is a nonprotein marine toxin which consists of a long, partially unsaturated (with eight double bonds) aliphatic backbone with spaced cyclic ethers and 64 chiral centers [4]. Initially isolated from a Palythoa species (Anthozoa: Zoantharia: Sphenopidae) [5], it can also be found in numerous other marine organisms from the same ecological region [6]. Moreover, several analogues of PITX were discovered in various organisms (Table 1). Currently, the biogenetic origin of PITX in Palythoa remains unclear. The leading hypothesis is that the toxin is synthesised by symbiotic dinoflagellates $[7,8]$ and/or by bacteria [9, 10]. To date, Palythoa heliodiscus is the largest PITX producer known among zoanthids, providing high yield of PITX (1 mg/g wet Palythoa $)$ and deoxyPITX (3.51 mg/g wet Palythoa) [11]. However, in most cases the toxin yield is very low. As a consequence, and because of sanitary problems due to toxic Ostreopsis spp. outbreaks [12], there is a need for high-yield sources of PITX so as to facilitate its functional characterisation. 
Sales from aquarium trade of zoanthids containing PITX have also caused domestic intoxications after inhalation of steam [13,14], dermal contact [15] or water spray in the eyes $[16,17]$.

PITX and its analogues bind and transform the $\mathrm{Na}^{+} / \mathrm{K}^{+}$-ATPase pump (NaK) into an open channel. The PITX binding site is coupled to other cardiac glycosides (CGs), such as ouabain which is known to bind the $\alpha$-subunit of $\mathrm{NaK}$ [18]. $\mathrm{NaK} \alpha$-subunit isoforms have a similar affinity for all CGs [19]. However, recent kinetic experiments revealed that PITX binding dissociation resulting from ouabain competition was incomplete, suggesting an additional, ouabain-insensitive, PITX binding site [2]. The ensuing ionic passive transport through NaK leads to the depolarization of the plasma membrane $[20,21]$ and affects the mechanisms controlling intracellular calcium $\left(\mathrm{Ca}^{2+}\right)$ concentration [22]. The intracellular $\mathrm{Ca}^{2+}$ increase is related to a long-lasting and gadolinium-sensitive $\mathrm{Ca}^{2+}$ influx suggesting a possible involvement of stretch-activated channels in PITX-induced cytotoxicity [23]. Furthermore, PITX mediates disruption of the actin cytoskeleton and cytomorphological changes [24, 25]. The massive increase of $\mathrm{Ca}^{2+}$ in the cytosol triggers the activation of cellular signalling pathways. As is the case with various CGs [26], mitogen activated protein kinases (MAPKs) mediate PITX-stimulated signalling and relay a variety of signals to the cellular machinery that regulates cell fate and function [27].

In this study, we have shown that aquacultured zoanthids from an undescribed species belonging to the Palythoa aff. clavata/sakurajimensis complex represent a new PITX source with the highest yield ever found. While PITX has been primarily identified as a tumour promoter when combined to carcinogenic compounds [28, 29], the PITX isolated from Palythoa sp. Pc001 exhibited high in vitro cytotoxic effects on cancer cells at picomolar doses. The $\mathrm{IC}_{50}$ concentrations calculated from MTT colorimetric assay associated with quantitative videomicroscopy showed that in vitro cytotoxicity is over 1000 times higher toward cancer cells than non-cancerous NHDF cells. Moreover, comparative MTT colorimetric assay for in vitro growth inhibitory effects on murine versus human cancer cell lines suggested that the targeting of the $\mathrm{NaK} \alpha$-subunit is not the sole mechanism underlying the cytotoxic effects of PITX. Based on these results PITX may be a very promising anticancer agent.

Table 1. Summary of the known molecules in the palytoxin family in Zoantharia, Cyanobacteria, algae and dinoflagellates.

\begin{tabular}{|c|c|c|}
\hline Compound & Organism & MW \\
\hline
\end{tabular}


bioRxiv preprint doi: https://doi.org/10.1101/292219; this version posted March 30, 2018. The copyright holder for this preprint (which was not certified by peer review) is the author/funder, who has granted bioRxiv a license to display the preprint in perpetuity. It is made available under aCC-BY-NC-ND 4.0 International license.

\begin{tabular}{|c|c|c|c|c|}
\hline Palytoxin & Palythoa aff. clavata & 2679 & $1810-2630 \mu \mathrm{g} / \mathrm{g}$ wet $\mathrm{z}$ & This study \\
\hline Palytoxin & P. toxica & 2679 & $275 \mu \mathrm{g} / \mathrm{g}$ wet $\mathrm{z}$ & Moore and Scheuer, 1971 [5] \\
\hline Palytoxin & P. tuberculosa & 2679 & $13.6 \mu \mathrm{g} / \mathrm{g}$ wet $\mathrm{z}$ & Kimura and Hashimoto, 1973 [30] \\
\hline Palytoxin & P. caribaeorum & 2679 & $30 \mu \mathrm{g} / \mathrm{g}$ wet $\mathrm{z}$ & Béress et al., 1983 [31] \\
\hline Palytoxin & P. heliodiscus & 2679 & $613 \mu \mathrm{g} / \mathrm{g}$ wet $\mathrm{z}$ & Deeds et al., 2011 [11] \\
\hline Palytoxin & P. heliodiscus & 2679 & $515 \mu \mathrm{g} / \mathrm{g}$ wet $\mathrm{z}$ & Deeds et al., 2011 [11] \\
\hline Palytoxin & P. heliodiscus & 2679 & $1164 \mu \mathrm{g} / \mathrm{g}$ wet $\mathrm{z}$ & Deeds et al., 2011 [11] \\
\hline Palytoxin & P. heliodiscus & 2679 & $1037 \mu \mathrm{g} / \mathrm{g}$ wet $\mathrm{z}$ & Deeds et al., 2011 [11] \\
\hline Palytoxin $^{1}$ & P. vestitus & ND & ND & Quinn et al., 1974 [32] \\
\hline Palytoxin & $P$. aff. margaritae & 2679 & ND & Oku et al., 2004 [33] \\
\hline Palytoxin $^{2}$ & Zoanthus solanderi & ND & ND & Gleibs et al., 1995 [34] \\
\hline Palytoxin $^{2}$ & Z. sociatus & ND & ND & Gleibs et al., 1995 [34] \\
\hline Palytoxin-b & P. tuberculosa & 2720 & minor & Rossi et al., 2010 [35] \\
\hline Homo-palytoxin & P. tuberculosa & 2692 & minor & Uemura et al., 1985 [4] \\
\hline Bishomo-palytoxin & P. tuberculosa & 2706 & minor & Uemura et al., 1985 [4] \\
\hline Neo-palytoxin & P. tuberculosa & 2661 & minor & Uemura et al., 1985 [4] \\
\hline 73-deoxy-palytoxin & P. tuberculosa & 2663 & minor & Uemura et al., 1985 [4] \\
\hline Deoxy-palytoxin ${ }^{3}$ & P. heliodiscus & 2663 & $3515 \mu \mathrm{g} / \mathrm{g}$ wet $\mathrm{z}$ & Deeds et al., 2011 [11] \\
\hline Deoxy-palytoxin ${ }^{3}$ & P. cf. toxica & 2662 & ND & Tartaglione et al., 2016 [36] \\
\hline 42-OH-palytoxin & P. tuberculosa & 2695 & minor & Ciminiello et al., 2009 [37] \\
\hline 42-OH-palytoxin & P. toxica & 2695 & minor & Ciminiello et al., 2009 [37] \\
\hline OH-palytoxin ${ }^{4}$ & P. cf. toxica & 2695 & ND & Tartaglione et al., 2016 [36] \\
\hline 42-OH-palytoxin ${ }^{5}$ & Trichodesmium spp. & 2695 & minor & Kerbrat et al., 2011 [38] \\
\hline CA-I ${ }^{6}$ & Chondria armata & ND & ND & Yasumoto and Murata, 1990 [39] \\
\hline $\mathrm{CA}-\mathrm{II}^{6}$ & C. armata & ND & ND & Yasumoto and Murata, 1990 [39] \\
\hline Mascarenotoxin-a & Ostreopsis ovata & 2588 & minor & Rossi et al., 2010 [35] \\
\hline Mascarenotoxin-a & O. mascarenensis & 2588 & minor & Lenoir et al., 2004 [40] \\
\hline Mascarenotoxin-b & O. mascarenensis & 2606 & minor & Lenoir et al., 2004 [40] \\
\hline Mascarenotoxin-c & O. ovata & 2628 & minor & Rossi et al., 2010 [35] \\
\hline Ostreocin-d & O. siamensis & 2634 & ND & Ukena et al., 2001 [41] \\
\hline Ovatoxin-a & O. ovata & 2646 & minor & Ciminiello et al., 2008 [42] \\
\hline Ovatoxin-b & O. ovata & 2662 & minor & Rossi et al., 2010 [35] \\
\hline Ovatoxin-c & O. ovata & 2690 & minor & Rossi et al., 2010 [35] \\
\hline Ovatoxin-d & O. ovata & 2706 & minor & Rossi et al., 2010 [35] \\
\hline
\end{tabular}

MW, molecular weight.ND, not determined.z, zoanthid. ${ }^{1}$ In absence of mass spectrometry data, the toxin found in Palythoa vestitus showed equivalent UV spectrum and toxicity against mice Ehrlich ascites tumor than P. tuberculosa toxin, and has been supposed to synthesize a similar palytoxin. ${ }^{2}$ For Zoanthus solanderi and Z. sociatus, presence of palytoxin in the extracts was only shown by HPLC comparatively to the palytoxin standard isolated from $P$. caribaeorum, but has never been characterised by mass spectrometry. ${ }^{3}$ Position of the deoxygenation was not determined for this analogue. ${ }^{4}$ Position of the oxygenation was not determined for this analogue. ${ }^{5}$ In this case, 42-hydroxy-palytoxin was the main toxin, palytoxin was present at only $10-20 \%$ of the total toxin amount. ${ }^{6}$ CA-I and CA-II are two palytoxin analogues in the red alga Chontria armata which mainly produces domoic acid. 


\section{Materials and methods}

Palythoa sp. Pc001 origin. Palythoa sp. Pc001 specimens used in this study were provided from the aquarium trade industry (Indonesia) and bred at Coral Biome's facility (Marseille). Specimens were maintained in a closed system aquaculture connected to a biological filter fed by artificial seawater (Instant Ocean salts, from Seachem, Madison, USA). Specimens were maintained at $26 \pm 1{ }^{\circ} \mathrm{C}$ and exposed to a daytime photoperiod of $12 \mathrm{~h}$ with an irradiance of 70 mol.quanta $\mathrm{m}^{-2} \cdot \mathrm{s}^{-1}$ and fed daily with fish food pellets (Formula One, from Ocean Nutrition, Essen, Belgium) to maximize growth rate.

DNA extraction, PCR amplification and sequencing. To amplify both Palythoa and Symbiodinium genes, tissue sample consisting of five tentacles joined by a small piece of polyp oral disc was placed in $80 \%$ alcohol. Total genomic DNA was extracted using the DNAeasy Kit (Qiagen, Valencia, CA). Two commonly used DNA barcode markers were amplified to identify the Palythoa sp. Pc001 specimens: the mitochondrial cytochrome oxidase subunit I (COI) and the nuclear internal transcribed spacer region of ribosomal DNA (ITS-rDNA, internal transcribed spacer 1, 5.8S ribosomal RNA gene, internal transcribed spacer 2). An ITS-rDNA sequence of approximately 750-850 base pairs was amplified using the primers Zoanf-ITS (5' - CTT GAT CAT TTA GAG GGA GT - 3') and Zoanr-ITS (5' CGG AGA TTT CAA ATT TGA GCT - 3'). The PCR program was carried out as follow: an initial denaturing step at $94^{\circ} \mathrm{C}$ for $3 \mathrm{~min}$, followed by 35 cycles of 1 min denaturation at $94^{\circ} \mathrm{C}$, $1 \mathrm{~min}$ annealing at $50^{\circ} \mathrm{C}, 2 \mathrm{~min}$ extension at $72^{\circ} \mathrm{C}$ followed by $10 \mathrm{~min}$ at $72^{\circ} \mathrm{C}$. The portion of the mitochondrial COI gene of approximately 650 base pairs was amplified with the following primers: HCO2198 (5' - TAA ACT TCA GGG TGA CCA AAA AAT CA - 3') and LCO1490 (5' - GGT CAA CAA ATC ATA AAG ATA TTG G - 3'). PCR amplification was performed as follow: an initial denaturing step at $94^{\circ} \mathrm{C}$ for 2 min followed by 5 cycles of $15 \mathrm{~s}$ denaturation at $92^{\circ} \mathrm{C}$, then $45 \mathrm{~s}$ annealing at $48^{\circ} \mathrm{C}$ followed by an incremental increase until $72^{\circ} \mathrm{C}$ in $1 \mathrm{~min}$, then $1 \mathrm{~min} 30$ extension at $72^{\circ} \mathrm{C}$, followed by 30 cycles of $15 \mathrm{~s}$ denaturation at $92^{\circ} \mathrm{C}, 45 \mathrm{~s}$ annealing at $52^{\circ} \mathrm{C}, 45 \mathrm{~s}$ extension at $72^{\circ} \mathrm{C}$, followed by $7 \mathrm{~min}$ at $72^{\circ} \mathrm{C}$.

To identify the Symbiodinium clade associated to Palythoa sp. Pc001, an ITS2-rDNA sequence (5.8S ribosomal RNA, partial sequence; internal transcribed spacer 2, complete sequence; 28S ribosomal RNA gene, partial sequence) of approximately 250-300 base pairs was amplified using the specific primers ITS2-F1 (5' - GAA TTG CAG AAC TCC GTG - 3') and ITS2-R2 (5' - ATA TGC TTA AAT TCA GCG GGT - 3'). PCR amplification was performed under stringent conditions to specifically target the Symbiodinium genes instead of 
coral ones: an initial denaturing step at $94^{\circ} \mathrm{C}$ for 3 min followed by 12 cycles of $45 \mathrm{~s}$ denaturation at $94^{\circ} \mathrm{C}, 45 \mathrm{~s}$ annealing at $58^{\circ} \mathrm{C}$ and an incremental decrease of $0.5^{\circ} \mathrm{C}$ every cycle, 1 min extension at $72^{\circ} \mathrm{C}$, followed by 20 cycles of $45 \mathrm{~s}$ denaturation at $94^{\circ} \mathrm{C}, 45 \mathrm{~s}$ annealing at $52^{\circ} \mathrm{C}$ and $1 \mathrm{~min}$ extension at $72^{\circ} \mathrm{C}$ followed by $7 \mathrm{~min}$ at $72^{\circ} \mathrm{C}$.

After amplification, all PCR fragments were visualised by denaturing gradient gel electrophoresis and were sequenced in both directions using the amplicon primers with an ABI 96-capillary 3730XL sequencer at Eurofins genomics (Ebersberg, Germany).

Phylogenetic analyses. Two data sets were used for molecular analyses: dataset 1 for Palythoa species with ITS-rDNA and COI concatenated sequences and dataset 2 for Symbiodinium with ITS2-rRNA sequences. All sequences obtained in this study were first checked using NCBI BLAST, then aligned with orthologous sequences available in public databases using CLUSTALW implemented in BioEdit v7.1.9 (http://www.mbio.ncsu.edu/bioedit/bioedit.html). The program MUSCLE [43] was also used to carry out a multiple alignment based on the Symbiodinium ITS2-rDNA sequences. The MODELTEST v3.0b4 program [44] was used to identify the best model of DNA evolution using Bayesian information criterion (BIC). Molecular analyses were conducted through neighbour-joining (NJ) and maximum likelihood (ML) methods, using MEGA v6.0 [45] and Bayesian inference (BI) employing MrBayes v3.2 [46]. Topological robustness was determined using 100 non-parametric bootstrap replicates for NJ and ML analyses. For BI, Markov Chain Monte Carlo searches were done with four chains for 1,000,000 generations, with a random starting tree, default priors and Markov chains (with default heating values) sampled every 1,000 generations.

\section{MALDI-IMS analyses and localisation of Symbiodinium cells in Palythoa Pc001 tissues.}

Polyps were collected from cultured colonies in aquariums, harvested with care, and then quickly frozen in a container of isopentane plunged in liquid nitrogen. After $5 \mathrm{~min}$, dry polyps were stored at $-80^{\circ} \mathrm{C}$ overnight. Tissue sections were cut using a Leica CM 1900 UV Microsystems cryostat (Leica Microsystems SAS) with a microtome chamber and a specimen holder chilled at $-20^{\circ} \mathrm{C}$. Sections of $18 \mu \mathrm{m}$ were made in crosswise directions at three levels of the polyp body. Lengthwise sections were also made in some specimens. Sections were thaw mounted onto Indium Tin Oxide coated microscopic slides (Bruker Daltonics) adapted for matrix-assisted laser desorption ionization imaging mass spectrometry (MALDI-IMS), and onto superfrost plus slides (Thermo Scientific) for epifluorescence imaging. Both types of 
target slides were dried in a desiccator for $45 \mathrm{~min}$. Polyps sections were scanned before matrix deposition with a histology slide scanner (Opticlab H850 scanner, Plustek). Then, 2,5dihydroxybenzoic (DHB) acid (Bruker, Daltonics), $30 \mathrm{mg} / \mathrm{mL}$ in 50/50 methanol $(\mathrm{MeOH}) / \mathrm{H}_{2} \mathrm{O} \quad 0.1 \%$ trifluoroacetic acid (TFA) was used as a matrix and applied on tissue sections using an automatic matrix sprayer (TM-Sprayer, HTX Technologies). MALDI calibration was carried out manually with a Peptide Calibration Standard 2 (Bruker Daltonics). MALDI-IMS analyses were performed using an Ultraflextreme mass spectrometer controlled by the FlexControl 3.3 software (Bruker Daltonics) in positive reflectron mode. MALDI-IMS sequences were created with FlexImaging 3.0 and the measurement region were manually defined with the previous histological images. The spatial resolution was set at 50 $\mu \mathrm{m}$ with a laser diameter of $20 \mu \mathrm{m}$, and 300 laser shots were accumulated for each spot. The laser power was optimised at the start directly on tissue and then fixed for the overall MALDI-IMS experiment. The images were opened with SCILS Lab v2.5 in RAW data with a baseline subtraction to maintain resolution of the average mass spectrum. Due to the high intensity of the PLTX signal, root mean square normalisation was chosen for a better visualization of the distribution. Endogenous auto fluorescence of chlorophyll and peridinin pigments of the Symbiodinium cell was revealed under an inverted microscope (Nikon Eclipse TE2000-U) using a filter cube B-2E/C corresponding to a medium band blue excitation. Images were acquired with NIS-Elements BR v2.30 imaging software.

PITX purification. About one gram of fresh Palythoa sp. Pc001 was gently detached from the substrate with a scalpel, chopped into several pieces and placed in $20 \mathrm{~mL}$ of $80 \%(\mathrm{v} / \mathrm{v})$ $\mathrm{MeOH}$ in milliQ $\mathrm{H}_{2} \mathrm{O}$. After agitation for $12 \mathrm{~h}$ at $4^{\circ} \mathrm{C}$, the extract was centrifuged $(8,000 \mathrm{~g}, 20$ min), the pellet rinsed with $5 \mathrm{~mL}$ milliQ $\mathrm{H}_{2} \mathrm{O}$, centrifuged $(8,000 \mathrm{~g}, 20 \mathrm{~min})$ and the supernatants were pooled. $\mathrm{MeOH}$ was evaporated using a rotavapor and the aqueous phase extracted several times with dichloromethane to remove carotenoid and chlorophyll pigments. The red-color (RC) organic phases were pooled, evaporated to dryness and kept at $4{ }^{\circ} \mathrm{C}$ in darkness for further pigment identification. The remaining aqueous phase that contained PITX was evaporated and deposited onto a two-centimeter diameter glass column filled with $10 \mathrm{~cm}^{3}$ of $\mathrm{C}_{18}$ reversed phase powder (Lichroprep $\mathrm{RP}_{18}$, from MERCK, France). The column was washed with acidified $\mathrm{H}_{2} \mathrm{O}(0.2 \%(\mathrm{v} / \mathrm{v})$ formic acid), then with $50 \%(\mathrm{v} / \mathrm{v}) \mathrm{MeOH}$ in acidified $\mathrm{H}_{2} \mathrm{O}$. PITX was finally eluted with $75 \%(\mathrm{v} / \mathrm{v}) \mathrm{MeOH}$ in acidified $\mathrm{H}_{2} \mathrm{O}$, and a dried paleyellow solid of pure PITX was obtained by $\mathrm{N}_{2}$ flow evaporation. The toxin was solubilised in dimethylsulfoxide (DMSO) and quantified by using high performance liquid chromatography (HPLC, see below). Routinely, preparations containing $100 \mu \mathrm{g}$ PITX in $100 \mu \mathrm{L}$ DMSO were 
stored at $4^{\circ} \mathrm{C}$ for up to 6 months. From the last purification step, a yellow carotenoid (YC) fraction retained on the Lichroprep-RP column was eluted by pure $\mathrm{MeOH}$, evaporated to dryness and stored at $4{ }^{\circ} \mathrm{C}$ in darkness for further identification.

HPLC analyses. Solvents were of HPLC grade and obtained from Biosolve (Dieuze, France). To control the purity of the PITX fraction and quantify the toxin, $2-5 \mu \mathrm{g}$ of the sample in milliQ $\mathrm{H}_{2} \mathrm{O}$ were injected and analysed by reverse-phase (RP) HPLC with a Waters equipment composed of a 1525 binary pump, a 2996 diode array detector, a 7725i Rheodyne injector fitted with a $20-\mu \mathrm{L}$ loop, and a temperature control system. Files were acquired by the Empower software. Separations were carried out on a Waters Symmetry $C_{18}$ column $(4.6 \times$ $100 \mathrm{~mm}$, ODS2, $5 \mu \mathrm{m}$ ) protected with a guard cartridge. The elution was performed at $30^{\circ} \mathrm{C}$ at a flow rate of $0.8 \mathrm{~mL} / \mathrm{min}$ and using a linear gradient of $\mathrm{MeOH}$ (eluent $\mathrm{A}$ ) in acidified $\mathrm{H}_{2} \mathrm{O}$ with $0.2 \%(\mathrm{v} / \mathrm{v})$ acetic acid (eluent B), from 5 to $100 \%$ A during 20 min. PITX was visualised at $263 \mathrm{~nm}$ and total spectra were analysed from 200 to $700 \mathrm{~nm}$ by the software to control the purity. Commercial PITX (from WAKO Pure Chemical Industries, Japan) was redissolved in DMSO and used for calibration. Data were averaged from three injections. The yield of PITX in Palythoa sp. Pc001 (expressed as mg/g of wet Palythoa) was determined by averaging the yields calculated from 12 animal extractions. Pigments from Symbiodinium and Palythoa sp. Pc001 (RC and YC) extracts were also analysed by the same HPLC device but using an Agilent Technologies Zorbax Eclipse XDB-C $\mathrm{C}_{8}$ column $(4.6 \times 150 \mathrm{~mm})$ eluted with the gradient method of Zapata et al. [47].

Mass spectrometry. Matrix-assisted laser desorption ionization time-of-flight (MALDI-ToF) analyses were performed on a Microflex II mass spectrometer (Bruker, Germany). A 10 $\mathrm{mg} / \mathrm{mL}$ solution of 2,5-DHB in 70/30 acetonitrile/ $\mathrm{H}_{2} \mathrm{O} 0.1 \%$ TFA was used as matrix [48]. From a solution of $1 \mathrm{mg} / \mathrm{mL}$ of purified toxin in milliQ $\mathrm{H}_{2} \mathrm{O}, 0.8 \mu \mathrm{L}$ were mixed with $0.8 \mu \mathrm{L}$ of the matrix solution, deposited and allowed to dry at room temperature. Data were acquired in a positive reflectron mode, the range was set from 600 to $5000 \mathrm{Da}$, and pulsed ion extraction was fixed at $150 \mathrm{~ns}$. Ions formed upon irradiation by a smartbeam laser using a frequency of $200 \mathrm{~Hz}$. The laser irradiance was set to $45-50 \%$ (relative scale 0-100) arbitrary units according to the corresponding threshold required for the applied matrix system. Mass spectra were treated with the Flex Analysis software (Bruker, Germany) and no smoothing or baseline subtraction was performed. Purified PITX was also analysed by ESI-MS/MS on a QToF Synapt G1 High Definition mass spectrometer (Waters, UK) mounted with a nanospray 
ionization source and a V-mono-reflectron, in the positive mode. The following source settings were used: capillary voltage $3.2 \mathrm{kV}$, sampling cone $40 \mathrm{~V}$, extraction cone $4 \mathrm{~V}$, source temperature $120^{\circ} \mathrm{C}$, desolvation gas flow $200 \mathrm{~L} / \mathrm{h}\left(\mathrm{N}_{2}\right)$ at a temperature of $150^{\circ} \mathrm{C}$, and trap collision energy $38 \mathrm{eV}$. The calibration was performed with a solution of CsI $1 \mathrm{mg} / \mathrm{mL}$ and used in the 100-3200 mass range with a precision of $+/-3 \mathrm{ppm}$. A solution of purified PITX (1 $\mathrm{mg} / \mathrm{mL})$ in $\mathrm{MeOH} / \mathrm{H}_{2} \mathrm{O}(1: 1)$ was diluted 25 times (15 $\mu \mathrm{M}$ final concentration) and injected via a syringe pump in the nano-source at a flow rate of $3 \mu \mathrm{L} / \mathrm{min}$.

Carotenoids and chlorophylls identification. $\mathrm{RC}$ and $\mathrm{YC}$ fractions obtained previously as dried matter (see PITX purification) were each dissolved in $1 \mathrm{~mL}$ of $\mathrm{MeOH}$ and $10-20 \mu \mathrm{L}$ were directly analysed by HPLC on a $\mathrm{C}_{8}$ reverse-phase column. For comparison, photosynthetic pigments were also extracted from a pellet containing fresh Symbiodinium cells with $5 \mathrm{~mL}$ of a MeOH- $\mathrm{H}_{2} \mathrm{O}$ (4:1) mixture under agitation with a magnetic barrel for $2 \mathrm{~h}$ at $4^{\circ} \mathrm{C}$ in darkness. After centrifugation $(10,000 \mathrm{~g}, 5 \mathrm{~min})$, the coloured supernatant was slightly evaporated and $20 \mu \mathrm{L}$ were directly analysed by HPLC. Symbiodinium cells were isolated according to a protocol adapted from Perez and Weis [49]. This involved cutting in half three polyps and homogenizing each half in a glass tissue grinder with $1 \mathrm{~mL}$ of filtered artificial seawater. After decantation and leaving pieces of Palythoa sp. Pc001 in the bottom grinder, the six solutions were pooled and centrifuged at $450 \mathrm{~g}$ for $5 \mathrm{~min}$ to pellet the algae which were then washed in three changes of seawater.

Cell lines and culture media. All medium components were purchased from Lonza (Westburg, Germany). The cell lines were purchased from the following bank collections: the American Type Culture Collection (ATCC, Manassas, USA); the European Collection of Cell Cultures (ECACC, Salisbury, UK); the Deutsche Sammlung von Mikroorganismen und Zellkulturen (DSMZ, Braunschweig, Germany); the Cell Line Services (CLS, Eppelheim, Germany); PromoCell (PC, Europe). The non-cancerous cell line used was the normal human dermal fibroblast (NHDF; PC C12300). The cancer cell lines sensitive to pro-apoptotic stimuli used here included the human Hs683 oligodendroglioma (ATCC HTB-138) and the mouse B16F10 melanoma (ATCC CRL6475) cell lines [50, 51, 52]. The cancer cell lines displaying various levels of resistance to pro-apoptotic stimuli included the human A549 nonsmall-cell lung cancer (NSCLC; DSMZ ACC-107), the human U373 glioblastoma cells (ECACC08061901) [50, 53], and the rodent 9L gliosarcoma cells. The human HBL-100 (CLS 330178) epithelial cell line was also included as a non-cancerous but transformed model. All 
cell lines except NHDF were cultured in RPMI 1640 culture medium supplemented with 10\% heat-inactivated FBS and a mixture of glutamine $0.6 \mathrm{mg} / \mathrm{mL}$, penicillin $200 \mathrm{IU} / \mathrm{mL}$, streptomycin $200 \mathrm{IU} / \mathrm{mL}$ and gentamycin $0.1 \mathrm{mg} / \mathrm{mL}$ (all at final concentration). The NHDF cell line was cultured in an MEM culture medium with 5\% heat-inactivated FBS and antibiotics as described above.

MTT colorimetric assay and quantitative videomicroscopy. The MTT colorimetric assay was used in order to determine the in vitro IC50 growth inhibitory concentrations of PITX. The MTT colorimetric assay was performed on the panel of cell lines listed above as detailed in [53]. Cell lines were plated according to their growth rate and left to adhere and grow for $24 \mathrm{~h}$ before treatment. Cells were then treated for $72 \mathrm{~h}$ with different concentrations of purified PITX in DMSO ranging from $1 \mathrm{pM}$ to $1 \mu \mathrm{M}$, with a semi-log concentration increase. After the treatment period, cells were incubated with the 3-(4,5-dimethylthiazol-2-yl)-2,5diphenyl tetrazolium bromide (MTT) solution to enable mitochondrial reduction. Blue formazan was solubilised with DMSO, and optical density was measured at $570 \mathrm{~nm}$ (reference wavelength $610 \mathrm{~nm}$ ). The $\mathrm{IC}_{50}$ concentrations were calculated from 96-well plates in which each experimental condition was carried out in six replicates except for the control, which was carried out in 12 replicates.

Direct visualization of the PITX-induced effects on the cell proliferation and morphology of human Hs683 and U373n glioma cells was performed by means of time-lapse computerassisted phase contrast microscopy, i.e. quantitative videomicroscopy as previously described [54]. A picture of the same field was acquired every 4 min over a period of several hours. Movies were generated from these digitised images to enable a rapid viewing of the cell behaviour for the duration of the experiments in control versus treated experimental conditions. Experiments were carried out in tetraplicates in human Hs683 and U373 glioma cell lines in the absence (control) or the presence of PITX at 0.01 and $1 \mathrm{nM}$.

\section{Results}

Morphological description and molecular typing of Palythoa sp. Pc001. The sandencrusted button-like body, the oral disk and tentacles (approximately 60) are brown and punctuated with white dots (Fig 1). The oral disc, with a diameter of 10-15 mm, has green overtones with a whitish centre and a white strip that forms a radius crossing the centre of the oral disc. The sequences of ITS-rRNA and COI genes from 17 specimens of Palythoa 
(representing 10 species) and 4 specimens of Zoanthus (representing 4 species) were concatenated to increase the accuracy of the phylogenetic reconstructions. The total length of the concatenation based on the two genes was $1221 \mathrm{bp}$ (770 and $451 \mathrm{pb}$ ITS-rRNA and COI respectively). The best-fitting model $\mathrm{K} 2+\Gamma$ was used for all methods. BI was performed with the following settings: the model employed two substitution types $(n s t=2)$ with stationary state frequencies fixed to equal in order to get the K2 model (prset statefreqpr $=$ fixed(equal)). Rate variation across sites was modelled using a gamma distribution (rates = gamma). Sequences from Zoanthus kuroshio, Z. gigantus, Z. sansibaricus and Z. sociatus were used as outgroups (Fig 1). The monophyly of Palythoa genus was highly supported whatever the method considered (100 bootstrap value (bv) for NJ /100 bv for ML /1 posterior probability (pp) for BI). Monophyletic lineages within the Palythoa genus were identified with good support values. The first clade (100/100/1) contained Palythoa grandis as the sister group to the $P$. variabilis/P. heliodiscus complex (100/97/1). The second clade consisted of $P$. caribaeorum, P. tuberculosa and P. Mutuki, although this group was moderately supported (76/73/1). P. grandiflora appeared as the sister species to this assemblage but with low bv values (66/69/1). The new sequences obtained from Palythoa sp. Pc001 grouped within a well-supported clade containing $P$. sp. sakurajimensis (Japan) and $P$. aff. clavata (Florida) (99/91/1). However, the sister group relationship between Palythoa sp. Pc001 and P. sp. clavata was supported by BI only $(\mathrm{pp}=0.96)$.

Molecular typing of the Symbiodinium clade and pigment characterisation. After the sequencing step, the ITS2-rDNA sequence displayed clear chromatograms in both forward and reverse directions with no 'double-peaks', and therefore no cloning step was performed to investigate the intragenomic variability. The best fit model for data set 2 was $\mathrm{K} 2+\mathrm{I}$. Phylogenetic analysis of ITS2-rDNA sequences, which were rooted on midpoint, yielded well-resolved trees in which the main clades previously described in cnidarians received high support values whatever the method considered (Fig 2). Symbiodinium ITS2-rDNA sequence isolated from the Palythoa sp. Pc001 grouped within the 'generalist' clade C (93/100/0.94). To check the origin of the chlorophylls and carotenoids, total pigments were extracted from purified Symbiodinium cells and analysed by RP-HPLC-DAD on a $\mathrm{C}_{8}$ column. The eluted pigments were identified as peridinin (major pigment, retention time $13.4 \mathrm{~min}, \lambda \max 474 \mathrm{~nm}$ ) and its cis-isomer (minor, $13.8 \mathrm{~min}, 459 \mathrm{~nm}$ ), fucoxanthin (major, $18.2 \mathrm{~min}, 468 \mathrm{~nm}$ ) and its isomer (minor, $17.9 \mathrm{~min}, 461 \mathrm{~nm}$ ), diadinoxanthine (major, $23.0 \mathrm{~min},[422,446,477] \mathrm{nm}$ ) and dinoxanthin (minor, $24.0 \mathrm{~min}$, [416,441,469] nm), chlorophyll a (major, $34.0 \mathrm{~min}$, $[429,616,662] \mathrm{nm}$ ) and its epimer (major, $34.4 \mathrm{~min},[430,618,662] \mathrm{nm}$ ), and the very weak 
compounds chlorophyll $c_{2}(9.1 \mathrm{~min}, 450 \mathrm{~nm})$ and phaeophytin $a$ (hypothetic, $36.0 \mathrm{~min}$, $[409,607,660] \mathrm{nm})$ (profile not shown). No $\beta$-carotene was detected. In parallel, the dichloromethane $(\mathrm{RC})$ and the $\mathrm{C}_{18}(\mathrm{YC})$ fractions obtained during the PITX purification process were also analysed for their pigment content. Identical pigments comprising carotenoids and chlorophylls were found in the RC fraction, since carotenoids only were present at lower doses in the YC fraction (data not shown), indicating that the liquid-liquid extraction using dichloromethane removed the totality of the chlorophylls and a major part of the carotenoids which facilitated the subsequent purification steps.

Purification, quantification and characterisation of PITX. PITX was eluted as a pure compound at $75 \% \mathrm{MeOH}$ by HPLC and DAD acquisitions in the 200-700 $\mathrm{nm}$ range. The purified fraction was eluted as a symmetrical peak at about $80 \% \mathrm{MeOH}$ on the $\mathrm{C}_{18}$-HPLC column (Fig 3A) by using a $0.2 \%$ acetic acid in the aqueous solvent (eluent B), the retention time was $14.8 \mathrm{~min}$ instead of $15.8 \mathrm{~min}$ in a $1 \%$ acid concentration. The purified fraction displayed two UV bands characteristic of PITX at 233 and $263 \mathrm{~nm}$. The purity was controlled by $\mathrm{C}_{18}$-HPLC-DAD in the entire UV-visible range, and then by $\mathrm{C}_{8}$-HPLC-DAD to verify the presence of residual carotenoid/chlorophyll pigments. No pigment or other compound was detected. Specimens of Palythoa sp. Pc001 were found to produce $2.22 \pm 0.41 \mathrm{mg}$ of PITX/g wet Palythoa $(n=11)$, as evaluated by HPLC analyses (Table 1$)$.

The mass spectra corresponded to a single molecule free of contaminants (Fig 3B). Indeed, by using the optimised matrix of Paz et al. [48] composed of DHB in a $0.1 \%$ TFA/acetonitrile mixture (which gave better resolution than with a $\alpha$-cyano-4-hydroxycinnamic acid (HCCA) matrix), the MALDI-ToF mass spectrometry in the positive mode revealed single charged molecules containing mainly $\mathrm{Na}^{+}$and few $\mathrm{K}^{+}$ions. The purified toxin showed a clear ion profile with a prominent ion at $m / z 2701.421[\mathrm{M}+\mathrm{Na}]^{+}$corresponding to a molecular mass of 2678.43 (Fig 3B). Together with this main molecular ion, minor adducts at $m / z 2683.359$ [M $\left.+\mathrm{Na}-\mathrm{H}_{2} \mathrm{O}\right]^{+}, 2665.262\left[\mathrm{M}+\mathrm{Na}-2 \mathrm{H}_{2} \mathrm{O}\right]^{+}$, and $2717.396[\mathrm{M}+\mathrm{K}]^{+}$were found, confirming the high degree of PITX purity. ESI-tandem mass spectrometry analyses on a Q-ToF instrument were also performed to confirm the PITX structure, and revealed a complex ion pattern with multiply charged states. The cleavage between carbon 8 and 9 of the PITX was demonstrated by the loss of the A moiety which was recovered as a single fragment ion $[\mathrm{M}+$ $\mathrm{H}]^{+} m / z 327.126$ in the full MS spectra and corresponded to a $\mathrm{C}_{16} \mathrm{H}_{27} \mathrm{~N}_{2} \mathrm{O}_{5}$ part formula usually observed in PITX (data not shown). Other characteristic tri- and bi-charged ions were notably identified at $m / z 906.495[\mathrm{M}+2 \mathrm{H}+\mathrm{K}]^{3+}, 1351.750[\mathrm{M}+\mathrm{H}+\mathrm{Na}]^{2+}$, and 1359.741 
$[\mathrm{M}+\mathrm{H}+\mathrm{K}]^{2+}$ (data not show). Further, MS/MS assignations confirmed the presence of a single molecule in the final purified fraction. The calculation based on these tri- and bicharged ions, together with the MALDI-ToF data, attributed to the PITX of Palythoa sp. Pc001 a molecular weight of 2678.48, similar to that of PITX of P. tuberculosa, P. toxica, $P$. caribaeorum and P. heliodiscus (Table 1).

Localisation of PITX and Symbiodinium cells. Cross-sections were analysed by MALDIIMS to localise the PITX in Palythoa sp. Pc001 tissues. At the same time, chlorophyll and peridinin pigments were analysed by epifluorescence microscopy to localise Symbiodinium cells (Fig 4). PITX was easily identified by MALDI-IMS and displayed a non-homogeneous distribution in polyp tissues. The ectodermal tissues, e.g. the epidermis of the body wall and the pharynx, showed the highest concentrations of PITX (Fig 4A, B). PITX was also found in some tissues of endodermal origin but with concentrations usually lower than in the ectodermal ones (Fig 4A-F). Amongst the endodermal tissues, the outer side of the endodermal fold close to the epidermis and the inner layer around the pharynx contained the highest PITX concentrations (Fig 4A, B). Very few PITX was detected in the gastrodermis of the enteron and septa (Fig 4C-F). High concentrations of PITX were also detected in the mucus-like secretion surrounding the polyps, especially well visible in the sagittal sections executed along the apico basal axis of the body (data not shown). No PITX was observed in the tentacles whatever the tissue considered (Fig 4A, B). Sections were also analysed by epifluorescence microscopy to localise the endogenous auto fluorescence due to chlorophyll and peridinin pigments of the Symbiodinium cells (Fig 4G-I). A strong signal was detected in the epidermis of both the body wall and the tentacles, the endodermal fold (outer layer of the gastrodermis below the epidermis) at the level of the mouth opening and the inner layer of the gastrodermis constituting the enteron wall. The gastrodermis constituting the septa walls located in the median part of the body also contained numerous Symbiodinium cells (Fig 4H), the number of which significantly decreased towards the apex (Fig 4G) and the base (Fig 4I).

In vitro growth inhibitory effect on cancer cells lines and $\mathbf{I C}_{\mathbf{5 0}}$. The data obtained by means of the MTT colorimetric assay with PITX in terms of in vitro growth inhibitory effects in human non-cancerous versus rodent and human cancer cell lines were highly reproducible as illustrated in Table 2. Our results revealed that PITX-mediated sensitivity of the noncancerous and non-transformed NHDF cell line was $\sim 10^{6}$ orders of magnitude lower than that of the cancerous or HBL-100 transformed cell lines. Surprisingly, the HBL-100 cell line 
transformed for immortalisation behaved as a cancer, not as a non-cancerous normal cell line regarding the PITX growth inhibitory effects.

The incomplete competition between PITX and ouabain over the binding of the NaK $\alpha 1$ subunit suggests that this subunit is the main target of PITX [2]. To test this hypothesis, two rodent models were included in our assay, i.e. the B16F10 mouse melanoma and the 9L rat gliosarcoma cell lines. Indeed, rodents display a double mutation in the $\mathrm{NaK} \alpha 1$-subunit, they are therefore 100-1,000 times less sensitive to $\mathrm{NaK} \alpha$-subunit inhibitors like the $\mathrm{CG}$ UNBS1450, when compared to human cells [55-57]. Interestingly, the rodent cell lines displayed similar sensitivity to PITX-mediated in vitro growth inhibition when compared to human cells (Table 2). The mean $\mathrm{IC}_{50}$ calculated for cancer cell lines including the $\mathrm{IC}_{50}$ obtained for transformed HBL-100 cells was $0.53 \pm 0.05$ pM PITX. Videomicroscopy data illustrate the morphological pictures obtained with 0.01 and $1 \mathrm{nM}$ PITX on human Hs683 and U373 glioma apoptosis-resistant cells (Fig 5). The concentration of $0.01 \mathrm{nM}$ (i.e. $10 \mathrm{pM}$ ) represents $\sim 20$ times the $\mathrm{IC}_{50}$ in vitro growth inhibitory concentration associated with PITX (Table 2), while $1 \mathrm{nM}$ represents $\sim 2,000$ times this $\mathrm{IC}_{50}$ concentration. Both Hs683 and U373 cell lines began to die about $3 \mathrm{~h}$ and $5 \mathrm{~h}$ respectively after having been treated with $0.01 \mathrm{nM}$ PITX. Both cells died after $3 \mathrm{~h}$ post-treatment with $1 \mathrm{nM}$ of PITX. The morphological appearance of dying Hs683 and U373 cells treated with 1 nM PITX (Fig 5) is typical of cell swelling and bubbling occurring after the impairment of various ion channels and pumps, not only $\mathrm{NaK}$.

Table 2. $\mathrm{IC}_{50}$ in vitro growth inhibitory concentration by $50 \%$ after having cultivated the cells in presence of the Palythoa sp. Pc001 palytoxin for $72 \mathrm{~h}$.

\begin{tabular}{llll}
\hline Cell line & Phenotype & Origin & IC $_{\mathbf{5 0}}(\mathbf{p M})$ \\
\hline NHDF (dermal fibroblast) & Non-cancerous normal cell & Human & $>1 \times 10^{6}$ \\
\hline HBL-100 (mammary epithelial) & Non-cancerous immortalised cells & Human & 0.65 \\
A549 (lung carcinoma) & Cancer & Human & 0.67 \\
Hs683 (glioma) & Cancer & Human & 0.58 \\
U373n (glioma) & Cancer & Human & 0.56 \\
9L (gliosarcoma) & Cancer & Rat & 0.39 \\
B16F10 (melanoma) & Cancer & Mouse & 0.44 \\
\hline Mean \pm SEM & Cancer & Human and murine & $\mathbf{0 . 5 3} \pm \mathbf{0 . 0 5}$ \\
\hline
\end{tabular}

For calculation of the average, the $\mathrm{IC}_{50}$ value for $\mathrm{HBL}-100$ transformed cell line was included. 


\section{Discussion}

Taxonomic remarks on Palythoa sp. Pc001 and its Symbiodinium clade. The identification of the specimens used in this study is a crucial step given that (i) different Palythoa species might produce different types or stereo-isomers of PITX, (ii) the $\mathrm{IC}_{50}$ found here are remarkably lower than previous published data, a result that can be explained by differential pharmacological effects related to different isomers of PITX [58]. The unambiguous identification of a zoanthid species is not a trivial task, even for an expert taxonomist, mainly due to the lack of reliable diagnostic characters combined with high levels of intraspecific morphological variation [59-61]. Recent molecular studies suggested that several previously described species were simply redundant [61, 62]. Moreover, many of the remaining species exist in sibling pairs between the Atlantic and Indo-Pacific basins. Without collection location or genetic data, it is therefore simply impossible to tell species pairs apart. Our molecular analyses showed that the closest relative to Palythoa sp. Pc001 is Palythoa aff. clavata, an undescribed species found in Florida waters [62]. More recently, Reimer et al. [63] identified new specimens from Ascension Island belonging to the clavata complex. The morphology of Palythoa sp. Pc001 does not match with any Indo-Pacific Palythoa species but fits very well with a specimen from the Cape Verde Islands named Palythoa sp. 265 [64] which is also genetically very close to $P$. aff. clavata [62]. Unfortunately, we could not include Palythoa sp. 265 in our concatenated analysis since ITS-rRNA sequences are not available in public databases. Nevertheless, Reimer et al. [64] provided its COI sequence, the phylogenetic analysis of which confirmed a close relationship between Palythoa sp. 265 from the Cape Verde Islands and Palythoa sp. Pc001 (not shown). Molecular analyses have also shown that the undescribed Indo-Pacific species $P$. aff. sakurajimensis is genetically close to Palythoa sp. Pc001. However, this molecular result is not congruent with morphological data, emphasizing once more that, in zoanthids, genetic similarities do not necessarily reflect morphological ones. Species boundaries are based primarily on morphology and it is generally assumed that morphological variations reflect reproductive isolation with genetic differentiation. However, genetic studies and fertilization trials producing viable larvae suggest that morphologic and genetic distinctions are not always closely linked in corals (for review [65]). So far, even if it is reasonable to consider Palythoa sp. Pc001 as an undescribed species on the basis of its morphology and collection location, it is not possible to assess to which extent hybridization with $P$. aff. sakurajimensis occurs naturally on the reef. As found in P. aff. clavata [63] and Palythoa sp. 265 [64], Palythoa sp. Pc001 contains a 'generalist' Symbiodinium belonging to clade C. A comparison of published results with the range of pigments synthesised by the Symbiodinium sp. found in Palythoa sp. Pc001 suggests that these pigments are synthesised 
only by the Symbiodinium cells (see $[47,66,67]$ ). This, in turns, supports that Palythoa sp. Pc001 seem not to be associated with epizoic or endolithic Cyanobacteria, green algae and diatoms, in contrast to other corals [67].

Storage of PITX in Palythoa sp. Pc001. Palythoa sp. Pc001 contains the highest amount of PITX ever found in a zoanthid $(2.22 \pm 0.41 \mathrm{mg} / \mathrm{g}$ wet zoanthid). The mean recorded value of $0.22 \%(\mathrm{w} / \mathrm{w})$ PITX is high compared to the values found in the literature (see Table 1), and corresponds to eight times more than the first value of $0.027 \%(\mathrm{w} / \mathrm{w})$ recorded by Moore and Sheuer [5] from P. toxica. In P. heliodiscus, Deeds et al. [11] found a maximum of $1164 \mu \mathrm{g} / \mathrm{g}$ wet zoanthid for PITX corresponding to $0.12 \%(\mathrm{w} / \mathrm{w})$. The PITX synthetic pathway and the putative symbiotic organism(s) involved are entirely unknown [6]. Based on structure similarities between PITX and zooxanthellatoxins, these last being secreted by Symbiodinium spp. [7, 8, 68], it has been hypothesised that the symbiotic dinoflagellates in Palythoa are responsible for PITX synthesis. Moreover, several species of free dinoflagellates are able to produce PITX and analogues [35, 40, 41, 42]. MALDI-IMS carried out on Palythoa sp. Pc001 tissues did not highlight an exclusive colocalisation of Symbiodinium cells and high levels of PITX. Strikingly, high levels of PITX could be detected in histological regions where few or no Symbiodinium cells could be observed, notably in the epidermis forming the pharynx. This raises interesting questions about the storage process in toxic Palythoa species. PITX is unlikely to be able to diffuse through cellular membranes due to its large molecular mass. Hence the hypothesis of a central role of the Symbiodinium cells in PITX synthesis suggests that $(i)$ PITX migrates through the symbiosome membranes and the cytoplasmic membrane of the host cell thanks to a non-diffusive active transport and (ii) a storage pathway must exist in some cells of toxic Palythoa species. It is noteworthy that the PITX and its analogues are not only produced by dinoflagellates. PITX and one of its analogues, 42-hydroxy-PITX, have been shown to be produced by a marine cyanobacteria belonging to the genus Trichodesmium [38]. Frolova et al. [9] detected PITX-like compounds in Gram-negative Aeromonas sp. and Vibrio sp. bacteria using anti-PITX antibodies. Similarly, bacteria isolated from Palythoa caribaeorum were found to display a PITX-like haemolytic activity [10] confirming that several prokaryotic organisms can produce at least one PITX type. It is therefore possible to assume that the Symbiodinium spp. and symbiotic prokaryotes collaborate with the cnidarian host to produce and store PITX. Accordingly, the holobiont itself has a decisive role and provides a favourable environment where crucial organisms for the synthesis and storage of PITX are united. This could also explain the differences of toxicity between several genetically close species of zoanthids $[6,11,34]$ containing Symbiodinium spp. belonging to 
the same clade. In any event, identifying the organisms involved in the PITX synthesis would necessitate both confocal laser scan microscopy and immunolabelling methods associated with metabolomics.

\section{PITX from Palythoa sp. Pc001 is the most powerful anti-cancer CGs ever reported.}

Ouabain-related in vitro $\mathrm{IC}_{50}$ growth inhibitory effects are in the $10-100 \mathrm{nM}$ ranges of concentration [55, 56], thus $10^{4}$ to $10^{5}$ orders of magnitude higher than the $0.54 \pm 0.05 \times 10^{-12}$ $\mathrm{M}$ (picomolar) $\mathrm{IC}_{50}$ evaluated in this work against various cancer cell lines. UNBS1450 inhibits $\alpha 3 \beta 1 \mathrm{NaK}$ at $3.2 \mathrm{nM}$ and demonstrates a much higher inhibition of $\mathrm{NaK}$ than classic CGs, with potency $>200$ times greater than ouabain and $\sim 6$ times greater than digoxin [55]. However, the use of UNBS1450 at antiproliferative concentrations does not induce apoptosis or intracellular $\mathrm{Ca}^{2+}$ increases that are typically involved in CG-mediated cardiotoxicity [53]. Videomicroscopy experiments showed that in presence of $10 \mathrm{pM}$ of PITX isolated from Palythoa sp. Pc001, Hs683 oligodendroglioma and U373n glioblastoma cell lines died but with a delay for the pro-apoptotic resistant U373n cells. Both cell lines displayed swelling and bubbling behaviours characteristic to $\mathrm{NaK}$ impairment as well as other ion channels. It is known that changes in ion fluxes are the immediate effects of PITX on the cells. In particular, the increase of the $\mathrm{Na}^{+}$permeability leads to the membrane depolarization and to a secondary $\mathrm{Ca}^{2+}$ influx that may lead to multiple events regulated by $\mathrm{Ca}^{2+}$-dependent pathways [24, 25]. However, it has been shown at low concentrations (10-100 nM) that other CGs do not affect the ionic imbalance of the cell and bind nonpumping $\mathrm{NaK}$ localised in caveolae leading to activation of the Src tyrosine kinase and MAPKs [26, 29]. Several works previously described the effects of PITX on proliferation and survival of cancer cells in similar experimental conditions, i.e without a pre-treatment with ouabain. Valverde et al. [69] described the cytotoxic effect triggered by the P. caribaeorum PITX on neuroblastoma cells (ATCC CRL2267). A $24 \mathrm{~h}$ treatment with $1 \mathrm{nM}$ of PITX inhibited up to over $50 \%$ cell proliferation. Significant toxic effects of the P. caribaeorum PITX were also observed in head and neck squamous cell carcinoma cell lines with $\mathrm{L}_{50}$ of 1.5-3.5 $\mathrm{ng}$ PITX/mL (0.56-1.30 nM), in contrast to healthy epithelial cells [1]. Furthermore, Kerbrat et al. [38] reported an $\mathrm{IC}_{50}$ of 170 pM with neuroblastoma cells (ATCC CCL-131) incubated for $22 \mathrm{~h}$ with a PITX mixture mainly composed of the 42-hydroxy isomer from the cyanobacteria Trichodesmium sp. Finally, Ledreux et al. [70] reported an $\mathrm{IC}_{50}$ value of $42.9 \pm 3.8 \mathrm{pM}$ in experiments carried out on Neuro2a cell line with a PITX incubation time of $19 \mathrm{~h}$. 
What could explain the higher cytotoxicity of the PITX isolated from Palythoa sp. Pc001? The molecular weight of $2679 \mathrm{Da}$ and the fragmentation recorded by mass spectrometry show that the Palythoa sp. Pc001 toxin is a 'classic' PITX similar to that isolated from P. toxica, $P$. tuberculosa and P. caribaeorum [5, 30, 31]. However, different stereo-isomers may be isolated from different Palythoa species. For instance, successive NMR-based stereostructural studies revealed that the two 42-hydroxy-PITXs isolated from P. toxica and P. tuberculosa were diastereo-isomers with inverted configurations at C50 [58]. Interestingly, the cytotoxicity of 42-hydroxy-50R-PITX from P. tuberculosa toward skin HaCaT keratinocytes appeared approximately two orders of magnitude lower than that of PITX and one order of magnitude lower than that of 42-hydroxy-PITX isolated from $P$. toxica [58]. The configurational inversion at C50 likely causes the 42-hydroxy-50R-PITX to undergo conformational changes that ultimately reduce its toxicity $[2,58,71]$.

PITX from Palythoa sp. Pc001 acts through unknown NaK binding sites. Ouabain, a potent blocker of the $\mathrm{NaK}$ used to inhibit some PITX effects in vitro, can displace PITX binding on purified $\mathrm{NaK}[18,72]$. The binding site for ouabain is restricted to the N-terminal 200 amino acids of the $\mathrm{NaK} \alpha$-subunit [73]. Data obtained here suggest that the PITX binding abilities are not only restricted to binding site for ouabain on the NaK $\alpha$-subunit. Indeed, we showed similar in vitro growth inhibitory activity in rodent and human cancer cells although the $\mathrm{NaK}$ in rodents displays double mutation in the $\alpha 1$-subunit which decreases the sensitivity to NaK inhibitors like UNBS1450 from 100 up to 1,000 times, when compared to human cells [55-57]. Furthermore, it has been demonstrated that PITX and ouabain could simultaneously bind to $\mathrm{NaK}$ [74] and a study on immortal human skin keratinocytes (HaCaT) supports the existence of both ouabain-sensitive and -insensitive PITX binding sites [2]. Together with our results, all of the above strengthens the hypothesis that PITX-induced cytotoxic effects via $\mathrm{NaK}$ might be mediated by binding sites that are distinct and/or partially overlapping with the $\alpha$-subunit traditionally identified for other CGs.

PITX from Palythoa sp. Pc001 showed a specific cytotoxicity towards cancer cells. PITX from Palythoa sp. Pc001 shows an exceptionally in vitro growth inhibitory activity on cancer cells which is $\sim 10^{6}$ orders of magnitude higher than on non-cancerous normal cells. This is the broadest differential cytotoxicity of potent NaK ligands ever reported [55-57]. Moreover, the in vitro growth inhibitory activity induced by PITX on cancer cells, associated with sensitivity to pro-apoptotic stimuli, was similar to the activity observed in those associated 
with various levels of resistance to pro-apoptotic stimuli. CGs are preferentially toxic to melanomas via the inhibition of NaK [75]. The CG UNBS1450 is significantly less active (in terms of in vitro growth inhibition) in normal fibroblasts (WI-38) than in NSCLC (A549 andCal-12T; [55]) and glioblastoma cells (T98G and U373; [57]). Considering the high cytotoxicity at very low doses towards cancer cells demonstrated here, PITX from Palythoa sp. Pc001 represents a very promising anti-cancer agent. However, due to the lack of knowledge concerning the mechanisms of action of PITX via NaK, it is difficult to explain this puzzling differential cytotoxicity. Several physiological explanations related to different cancer phenotypes can nevertheless be suggested. First, the number of $\mathrm{NaK}$ might be different in various cancer cells. While the $\alpha 1$ subunit of $\mathrm{NaK}$ is highly expressed in glioblastomas compared with normal tissues [57], Rajasekaran et al. [76] showed a down regulation of the $\beta 1$-subunit in renal cell carcinoma accompanied by a significant reduction in the $\mathrm{NaK}$ activity. A low NaK activity may consequently increase the PITX toxicity in some cancer cells. Second, one can also suggest that the heterodimers constituting the $\mathrm{NaK}$ in cancer cells are different and able to increase the death consecutive to the binding of PITX on particular isoforms. However, several publications emphasised the altered expression of $\mathrm{NaK}$ subunits in cancer cells when compared to corresponding normal ones. Different cancer types are characterised by over-expression of different $\alpha$ - and $\beta$-subunits and the presence of specific additional regulatory polypeptides, like FXYD proteins or transporters modifying the $\mathrm{NaK}$ kinetic properties [56]. Targeting the metabolic differences between cancer and normal cells holds promise as a novel anti-cancer strategy [77]. Cancer cells usually use high level of ATP for their enhanced glycolytic metabolism (Warburg effect, [78]). Distinct UNBS1450mediated in vitro growth inhibitory effects between normal and cancer cells seemed to be correlated with a lower ATP level in cancer than in normal cells [57]. Therefore, cancer cells might compensate less efficiently the ionic imbalance after a PITX treatment than healthy cells because of a lower ATP level.

Given that, the above observations raise two questions. Does the treatment with PITX interfere with the glucose metabolism and preferentially reduce ATP level in cancer cells? Is the ATP level in cancer cells sufficient to maintain a healthy metabolism after incubation with picomolar doses of PITX? To explore that, further experiments are needed. In particular, it will be useful to study intracellular signalling pathways and modification of the ATP level triggered by the PITX both in cancer and normal cells, in addition to transcriptome analysis using next-generation sequencing in regard to cancer metabolism and PITX cytotoxicity. 


\section{Competing interests}

The authors declare that they have no competing interests.

\section{Authors' contributions}

LS and YP carried out the molecular experiments and phylogenetic analyses. LS and JL did the PITX purification, HPLC and mass spectrometry experiments as well as pigment identification. LS, CN and JL did the MALDI-IMS analyses. FG maintained the clonal population of Palythoa sp. Pc001. JL, YP and LS drafted the manuscript. JL and YP conceived and supervised the study. All authors read, amended and approved the final manuscript.

\section{Acknowledgements}

We are deeply grateful to Céline Bruyère and Véronique Mathieu who provided cell lines and carried out MTT colorimetric assay and quantitative videomicroscopy experiments. Our manuscript benefits from stimulating discussion with Véronique Mathieu and Daniel Papillon who also provided English corrections. This study was financially supported by Coral Biome and Agence Nationale pour la Recherche et la Technologie (France), and IRD. Ludovic Sawelew is working for his $\mathrm{PhD}$ project under the CIFRE agreement 2014/0245 (Industrial agreement between Coral Biome and IRD).

\section{References}

1. Görögh T, Bèress L, Quabius ES, Ambrosch P, Hoffmann M. Head and neck cancer cells and xenografts are very sensitive to palytoxin: decrease of c-jun n-terminal kinase-3 expression enhances palytoxin toxicity. Mol Cancer. 2013;12: 1-11.

2. Pelin M, Boscolo S, Poli M, Sosa S, Tubaro A, Florio C. Characterization of palytoxin binding to HaCaT cells using a monoclonal anti-palytoxin antibody. Mar Drugs. 2013;11: 584-598.

3. Wiles JS, Vick JA, Christensen MK. Toxicological evaluation of palytoxin in several animal species. Toxicon. 1974;12: 427-433.

4. Uemura D, Hirata Y, Iwashita T, Naoki H. Studies on palytoxins. Tetrahedron. 1985;41: 1007-1017. 
5. Moore RE, Scheuer PJ. Palytoxin, new marine toxin from a Coelenterate. Science. 1971;172: 495-498.

6. Aratake S, Taira Y, Fujii T, Roy MC, Reimer JD, Yamazaki T, Jenke-Kodama H. Distribution of palytoxin in coral reef organisms living in close proximity to an aggregation of Palythoa tuberculosa. Toxicon. 2016;111: 86-90.

7. Nakamura H, Asari T, Ohizumi Y, Kobayashi J, Yamasu T, Murai A. Isolation of Zooxanthellatoxins, novel vasoconstrictive substances from the zooxanthella Symbiodinium sp. Toxicon. 1993;31: 371-376.

8. Onodera KI, Nakamura H, Oba Y, Ojika M. Zooxanthellamide B, a novel large polyhydroxy metabolite from a marine dinoflagellate of Symbiodinium sp. Biosci Biotech Bioch. 2004;68: 955-958.

9. Frolova GM, Kuznetsova TA, Mikhailov VV, Elyakov GB. An enzyme linked immunosorbent assay for detecting palytoxin-producing bacteria. Russ J Bioorg Chem. 2000;26: 285-289.

10. Seemann P, Gernert C, Schmitt S, Mebs D, Hentschel U. Detection of hemolytic bacteria from Palythoa caribaeorum (Cnidaria, Zoantharia) using a novel palytoxinscreening assay. Anton Leeuw Int J G. 2009;96: 405-411.

11. Deeds JR, Handy SM, White K, Reimer JD. Palytoxin found in Palythoa sp. Zoanthids (Anthozoa, Hexacorallia) sold in the home aquarium trade. PLOS One. 2011;6: 1-9.

12. Del Favero G, Sosa S, Pelin M, D'Orlando E, Florio C, Lorenzon P, et al. Sanitary problems related to the presence of Ostreopsis spp. in the Mediterranean Sea: a multidisciplinary scientific approach. Ann Ist Super Sanità. 2012;48: 407-414.

13. Snoeks L, Veenstra J. Family with fever after cleaning a sea aquarium. Ned Tijdsch Geneeskd. 2012;156: A4200.

14. Hall C, Levy D, Sattler S. A case of palytoxin poisoning in a home aquarium enthusiast and his family. Case Rep Emerg Med. 2015;621815.

15. Nordt SP, Wu J, Zahller S, Clark RF, Cantrell FL. Palytoxin poisoning after dermal contact with zoanthid coral. J Emerg Med. 2011;40: 397-399.

16. Moshirfar M, Khalifa YM, Espandar L, Mifflin MD. Aquarium coral keratoconjunctivitis. Arch Ophthalmol. 2010;128: 1360-1362.

17. Ruiz Y, Fuchs J, Beuschel R, Tschopp M, Goldblum D. Dangerous reef aquaristics: Palytoxin of a brown encrusting anemone causes toxic corneal reactions. Toxicon. 2015;106: 42-45. 
18. Habermann E, Chhatwal GS. Ouabain inhibits the increase due to palytoxin of cation permeability of erythrocytes. Naunyn-Schmiedeberg's Arch of Pharmacol. 1982;319: 101-107.

19. Wang J, Velotta JB, McDonough AA, Farley RA. All human Na+/K+ ATPase $\alpha-$ subunit isoforms have a similar affinity for cardiac glycosides. Am J Physiol Cell Physiol. 2001;281: C1336-C1343.

20. Kudo Y, Shibata S. The potent depolarizing action of palytoxin isolated from Palythoa tuberculosa on the isolated spinal cord of the frog. Br J Pharmac. 1980;71: 575-579.

21. Rossini GP, Bigiani A. Palytoxin action on the $\mathrm{Na}^{+}, \mathrm{K}^{+}$-ATPase and the disruption of ion equilibria in biological systems. Toxicon. 2011;57: 429-439.

22. Satoh E, Ishii T, Nishimura M. Palytoxin-induced increase in cytosolic-free $\mathrm{Ca}^{2+}$ in mouse spleen cells. Eur J Pharmacol. 2003;465: 9-13.

23. Del Favero G, Florio C, Codan B, Sosa S, Poli M, Sbaizero O, et al. The stretchactivated channel blocker $\mathrm{gd}^{3+}$ reduces palytoxin toxicity in primary cultures of skeletal muscle cells. Chem Res Toxicol. 2012;25: 1912-1920.

24. Louzao MC, Ares IR, Cagide E. Marine toxins and the cytoskeleton: a new view of palytoxin toxicity. FEBS J. 2008;275: 6067-6074.

25. Louzao MC, Ares IR, Cagide E, Espina B, Vilarino N, Alfonso A, et al. 2011. Palytoxins and cytoskeleton: An overview. Toxicon. 2011;57: 460-469.

26. Haas M, Wang H, Tian J, Xie Z. Src-mediated inter-receptor cross-talk between the $\mathrm{Na}+/ \mathrm{K}+$-ATPase and the epidermal growth factor receptor relays the signal from ouabain to mitogen-activated protein kinases. J Biol Chem. 2002;277: 18694-18702.

27. Wattenberg EV. Modulation of protein kinase signalling cascades by palytoxin. Toxicon. 2011;57: 440-448.

28. Fujiki H, Suganuma M, Nakayasu M, Hakii H, Horiuchi T, Takayama S, Sugimura T. Palytoxin is a non-12-O-tetradecanoylphorbol-13-acetate type tumor promoter in twostage mouse skin carcinogenesis. Carcinogenesis. 1986; 7: 707-710.

29. Wattenberg EV. Palytoxin: exploiting a novel skin tumor promoter to explore signal transduction and carcinogenesis. Am J Physiol. 2007;292: C24-32.

30. Kimura S, Hashimoto K. Purification of the toxin in a zoanthid Palythoa tuberculosa. Seto Marine Biol Lab. 1973;20: 713-718.

31. Béress L, Zwick J, Kolkenbrock HJ, Kaul PN, Wassermann O. A method for the isolation of the caribbean palytoxin (C-PTX) from the coelenterate (zooanthid) Palythoa caribaeorum. Toxicon. 1983;21: 285-290. 
32. Quinn RJ, Kashiwagi M, Moore RE, Norton TR. Anticancer activity of zoanthids and the associated toxin, palytoxin, against ehrlich ascites tumor and p-388 lymphocytic leukemia in mice. J Pharmac Sci. 1974;63: 257-260.

33. Oku N, Sata NU, Matsunaga S, Uchida H, Fusetani N. Identification of palytoxin as a principle which causes morphological changes in rat 3Y1 cells in the zoanthid Palythoa aff. margaritae. Toxicon. 2004;43: 21-25.

34. Gleibs S, Mebs D, Weerding B. Studies on the origin and distribution of palytoxin in a Caribbean coral reef. Toxicon. 1995;33: 1531-1537.

35. Rossi R, Castellano V, Scalco E, Serpe L, Zingone A, Soprano V. New palytoxin-like molecules in Mediterranean Ostreopsis cf. ovata (dinoflagellates) and in Palythoa tuberculosa detected by liquid chromatography-electrospray ionization time-of-flight mass spectrometry. Toxicon. 2010;56: 1381-1387.

36. Tartaglione L, Pelin M, Morpurgo M, Dell'Aversano C., Montenegro J, Sacco G, et al. An aquarium hobbyist poisoning: Identification of new palytoxins in Palythoa cf. toxica and complete detoxification of the aquarium water by activated carbon. Toxicon. 2006;121, 41-50.

37. Ciminiello P, Dell'Aversano C, DelloIacovo E, Fattorusso E, Forino M, Grauso L, et al. Stereostructure and biological activity of 42-hydroxy-palytoxin: a new palytoxin analogue from Hawaiian Palythoa subspecies. Chem Res Toxicol. 2009;22: 18511859.

38. Kerbrat AS, Amzil Z, Pawlowiez R, Golubic S, Sibat M, Darius HT, et al. First evidence of palytoxin and 42-hydroxy-palytoxin in the marine cyanobacterium Trichodesmium. Mar Drugs. 2011;9: 543-560.

39. Yasumoto T, Murata M. Polyether toxins involved in seafood poisoning. In: Hall S, G Strichartz, editors. Marine Toxins: origin, structure and molecular pharmacology. Washington D.C.: Am Chem Soc; 1990. pp. 120-132.

40. Lenoir S, Ten-Hage L, Turquet J, Quod JP, Bernard C, Hennion MC. First evidence of palytoxin analogues from an Ostreopsis mascarenensis (Dinophyceae) benthic bloom in southwestern Indian Ocean. J Phycol. 2004;40: 1042-1051.

41. Ukena T, Satake M, Usami M, Oshima Y, Naoki H, Fujita T, et al. Structure elucidation of ostreocin $\mathrm{D}$, a palytoxin analog isolated from the dinoflagellate Ostreopsis siamensis. Biosci Biotech Biochem. 2001;65: 2585-2588.

42. Ciminiello P, Dell'Aversano C, Fattorusso E, Forino M, Tartaglione L, Grillo C, Melchiorre N. Putative palytoxin and its new analogue, ovatoxin-a, in Ostreopsis 
ovata collected along the Ligurian Coasts during the 2006 toxic outbreak. J Am Soc Mass Spectr. 2008;19: 111-120.

43. Edgar RC. MUSCLE: multiple sequence alignment with high accuracy and high throughput. Nucleic Acids Res. 2004;32: 1792-1797.

44. Posada D, Crandall KA. MODELTEST: testing the model of DNA substitution. Bioinformatics. 1998;14: 817-818.

45. Tamura K, Stecher G, Peterson D, Filipski A, Kumar S. MEGA6: Molecular Evolutionary Genetics Analysis version 6.0. Mol Biol Evol. 2013;30: 2725-2729.

46. Ronquist F, Huelsenbeck JP. MrBayes 3: Bayesian phylogenetic inference undermixed models. Bioinformatics. 2003;19: 1572-1574.

47. Zapata M, Rodriguez F, Guarrido JL. Separation of chlorophylls and carotenoids from marine phytoplankton: a new HPLC method using a reversed phase $\mathrm{C}_{8}$ column and pyridine-containing mobile phases. Mar Ecol Prog Ser. 2000;195: 29-45.

48. Paz B, Riobo P, Franco JM. Preliminary study for rapid determination of phycotoxins in microalgae whole cells using matrix-assisted laser desorption ionization time-offlight mass spectrometry. Rapid Commun Mass Sp. 2011;25: 3627-3639.

49. Perez S, Weis VM. Nitric oxide and cnidarian bleaching: An eviction notice mediates the breakdown of symbiosis. J Exp Biol. 2006;209: 2804-2810.

50. Branle F, Lefranc F, Camby I, Jeuken J, Geurts-Moespot A, Sprenger S, et al. Evaluation of the efficiency of chemotherapy in in vivo orthotopic models of human glioma cells with and without $1 \mathrm{p} / 19 \mathrm{q}$ deletions and in C6 rat orthotopic allografts serving for the evaluation of surgery combined with chemotherapy. Cancer. 2002;95: 641-655.

51. Ingrassia L, Lefranc F, Dewelle J, Pottier L, Mathieu V, Spiegl-Kreinecker S, et al. Structure-activity-relationship analysis of novel derivatives of narciclasine (an Amaryllidaceae isocarbostyril alkaloid) as potential anti-cancer agents. J Med Chem. 2009;52: 1100-1114.

52. van Goietsenoven G, Hutton J, Becker JP, Lallemand B, Robert F, Lefranc F, et al. Targeting of eEF1A with Amaryllidaceae isocarbostyrils as a strategy to combat melanomas. FASEB J. 2010;24: 4575-4584.

53. Lefranc F, Mijatovic T, Kondo Y, Sauvage S, Roland I, Krstic D, et al. Targeting the alpha-1 subunit of the sodium pump (the $\mathrm{Na}^{+} / \mathrm{K}^{+}$-ATPase) to combat glioblastoma cells. Neurosurgery. 2008;62: 211-222.

54. Mijatovic T, Mathieu V, Gaussin JF, De Neve N, Ribaucour F, Van Quaquebeke E, et al. Cardenolide-induced lysosomal membrane permeabilization contributes therapeutic 
benefits in experimental human non-small-cell-lung cancers. Neoplasia. 2006;8: 402412.

55. Debeir O, Megalizzib V, Warzeea N, Kiss R, Decaesteckera C. Videomicroscopic extraction of specific information on cell proliferation and migration in vitro. Exp Cell Res. 2008;314: 2985-2998.

56. Mijatovic T, Roland I, Van Quaquebeke E, Nilsson B, Mathieu A, Van Vynckt F, et al. The alpha-1 subunit of the sodium pump could represent a novel target to combat non-small cell lung cancers. J Pathol. 2007;212: 170-179.

57. Mijatovic T, Van Quaquebeke E, Delest B, Debeir O, Darro F, Kiss R. Cardiotonic steroids on the road to anti-cancer therapy. Biochim Biophys Acta. 2007;1776: 32-57.

58. Ciminiello P, Dell'Aversano C, Dello Iacovo E, Forino M, Tartaglione L, Pelin M, et al. Stereoisomers of 42-hydroxy palytoxin from hawaiian Palythoa toxica and $P$. tuberculosa: Stereostructure elucidation, detection, and biological activities. J Nat Prod. 2014;77: 351-357.

59. Burnett WJ, Benzie JAH, Beardmore JA, Ryland JS. 1997. Zoanthids (Anthozoa, Hexacorallia) from the Great Barrier Reef and Torres Strait, Australia: systematics, evolution and a key to species. Coral Reefs. 1997;16: 55-68.

60. Fossa SA, Nilsen AJ. The modern coral reef aquarium 2. Bornheim (Germany): Birgit Schmettkamp Verlag; 1998.

61. Reimer JD, Ono S, Fujiwara Y, Takishita K, Tsukahara J. Reconsidering Zoanthus spp. diversity: molecular evidence of conspecifity within four previously presumed species. Zool Sci. 2004;21: 517-525

62. Reimer JD, Foord C, Irei Y. Species Diversity of Shallow Water Zoanthids (Cnidaria: Anthozoa: Hexacorallia) in Florida. J Mar Biol. 2012. doi:10.1155/2012/856079

63. Reimer JD, Lorion J, Irei Y, Hoeksema BW, Wirtz P. Ascension Island shallow-water Zoantharia (Hexacorallia: Cnidaria) and their zooxanthellae (Symbiodinium). J Mar Biol Assoc UK. 2014. doi:10.1017/S0025315414000654

64. Reimer JD, Hirose M, Wirtz P. Zoanthids of the Cape Verde Islands and their symbionts: previously unexamined diversity in the Northeastern Atlantic. Contrib Zool. 2010;79: 147-163.

65. Miller KJ, Benzie J. No clear genetic distinction between morphological species within the coral genus Platygyra. B Mar Sci. 1997;61: 907-917.

66. Venn AA, Wilson MA, Trapido-Rosenthal HG, Keely BJ, Douglas AE. The impact of coral bleaching on the pigment profile of the symbiotic alga, Symbiodinium. Plant Cell Environ J. 2006;29: 2133-2142. 
67. Daigo K, Nakano Y, Casareto BE, Suzuki Y, Shioi Y. High-performance liquid chromatographic analysis of photosynthetic pigments in corals: An existence of a variety of epizoic, endozoic and endolithic algae. Proc 11th Int Coral Reef Symp. 2008; 1: 123-127.

68. Drainville-Higgins KE. 2004. Isolation of marine metabolites from Symbiodinium species of dinoflagellates. Thesis. The university of Rhode Island. Available from: http://search.proquest.com/docview/305153556.

69. Valverde I, Lago J, Reboreda A, Vieites JM, Cabado AG. Characteristics of palytoxininduced cytotoxicity in neuroblastoma cells. Toxicol In Vitro. 2008;22: 1432-1439.

70. Ledreux A, Krys S, Bernard C. Suitability of the Neuro-2a cell line for the detection of palytoxin and analogues (neurotoxic phycotoxins). Toxicon. 2009;53: 300-308.

71. Del Favero G, Sosa S, Poli M, Tubaro A, Sbaizero O, Lorenzon P. In vivo and in vitro effects of 42-hydroxy-palytoxin on mouse skeletal muscle: Structural and functional impairment. Toxicol Lett. 2014;225: 285-293.

72. Tosteson MT, Scriven DRL, Bharadwaj AK, Kishi Y, Tosteson DC. Interaction of palytoxin with red cells: structure-function studies. Toxicon. 1995;33: 799-807.

73. Ishii T, K Takeyasu. The amino-terminal 200 amino acids of the plasma membrane $\mathrm{Na}^{+}, \mathrm{K}^{+}$-ATPase $\alpha$-subunit confer ouabain sensitivity on the sarcoplasmic reticulum $\mathrm{Ca}^{2+}$-ATPase. Proc Natl Acad Sci. 1993;90: 8881-8885.

74. Artigas $\mathrm{P}$, Gadsby DC. Large diameter of palytoxin-induced $\mathrm{Na} / \mathrm{K}$ pump channels and modulation of palytoxin interaction by Na/K pump ligands. J Gen Physiol. 2004;123: 357-376.

75. Eskiocak U, Ramesh V, Gill JG, Zhao Z, Yuan SW, Wang M, et al. Synergistic effects of ion transporter and MAP kinase pathway inhibitors in melanoma. Nat Commun. 2016; 7: 12336.

76. Rajasekaran SA, Ball WJ, Bander NH, Liu H, Pardee JD, Rajasekaran AK. Reduced expression of beta-subunit of Na,K-ATPase in human clear-cell renal cell carcinoma. $\mathrm{J}$ Urology. 1999;162: 574-80.

77. Martinez-Outschoorn UE, Peiris-Pagés M, Pestell RG, Sotgia F, Lisanti MP. Cancer metabolism: a therapeutic perspective. Nat Rev Clin Oncol. 2016 doi: 10.1038/nrclinonc.2016.60.

78. Tran Q, Lee H, Park J, Kim SH, Park J. Targeting cancer metabolism - revisiting the Warburg effects. Toxicol Res. 2016;32: 177-193. 

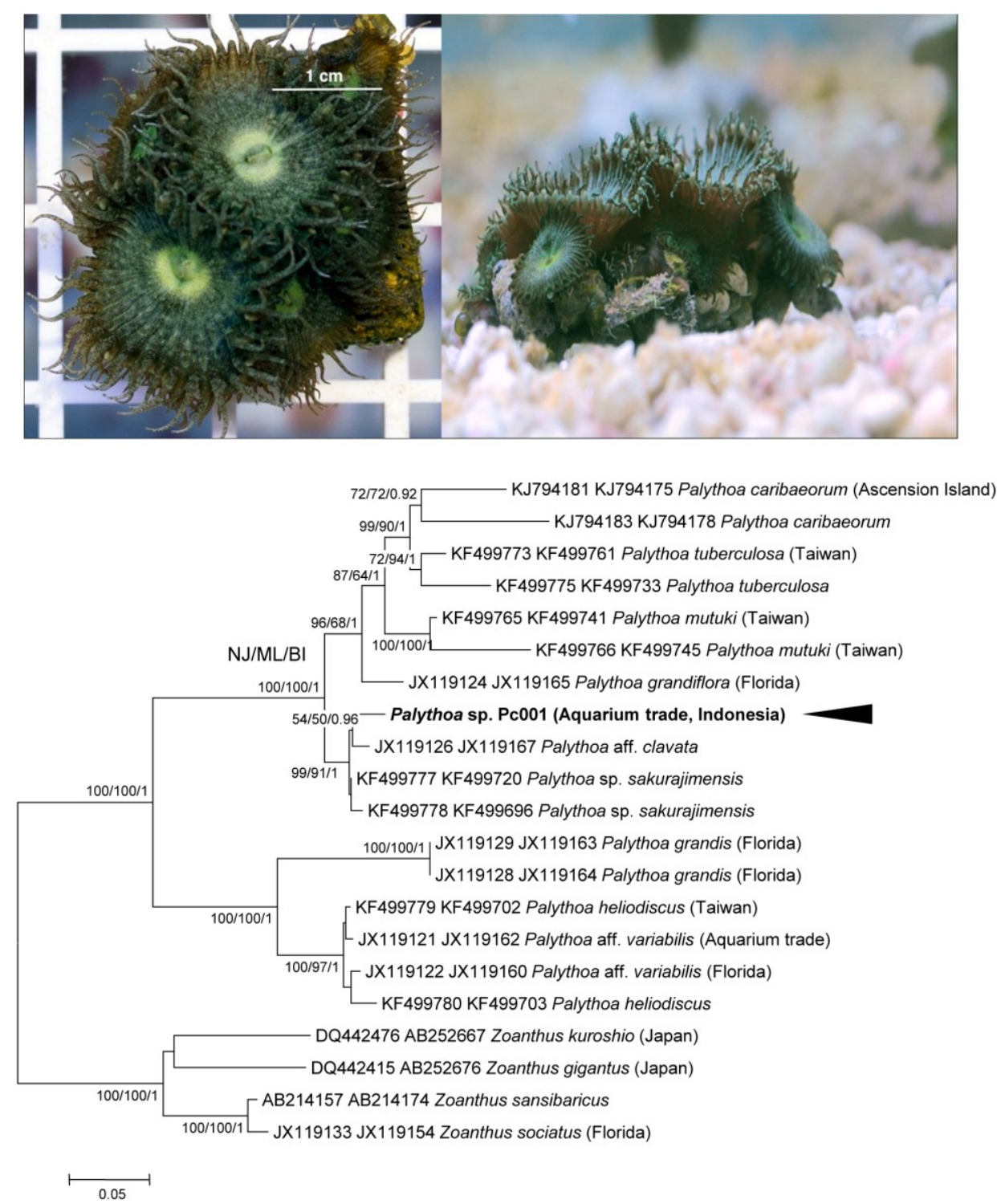

Figure 1. Morphotype and phylogenetical identification of Palythoa sp. Pc001 used in this study.

Top: two colonies of Palythoa sp. Pc001 collected in Indonesia and routinely cultivated in aquariums at Coral Biome. Bottom: maximum likelihood tree calculated from a supermatrix including ITS-rRNA and COI sequences (1221 nucleotide positions) under the K2 $+\Gamma$ model.

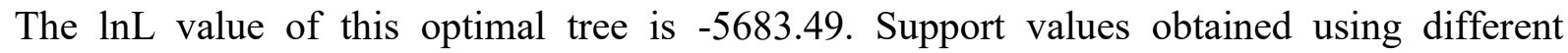
reconstruction approaches are indicated at nodes in the following order: neighbor joining (NJ), maximum likelihood (ML), and bayesian inference (BI). Support values are displayed when bootstrap values $\geq 70$ or posterior probabilities $p \geq 0.90$. Tree was rooted on the monophyletic assemblage consisting of 4 Zoanthus species. Black arrowhead indicates the sequence belonging to Palythoa sp. Pc001 used for palytoxin extraction. Sequences/species names from previous studies in regular font with GenBank Accession Numbers. 


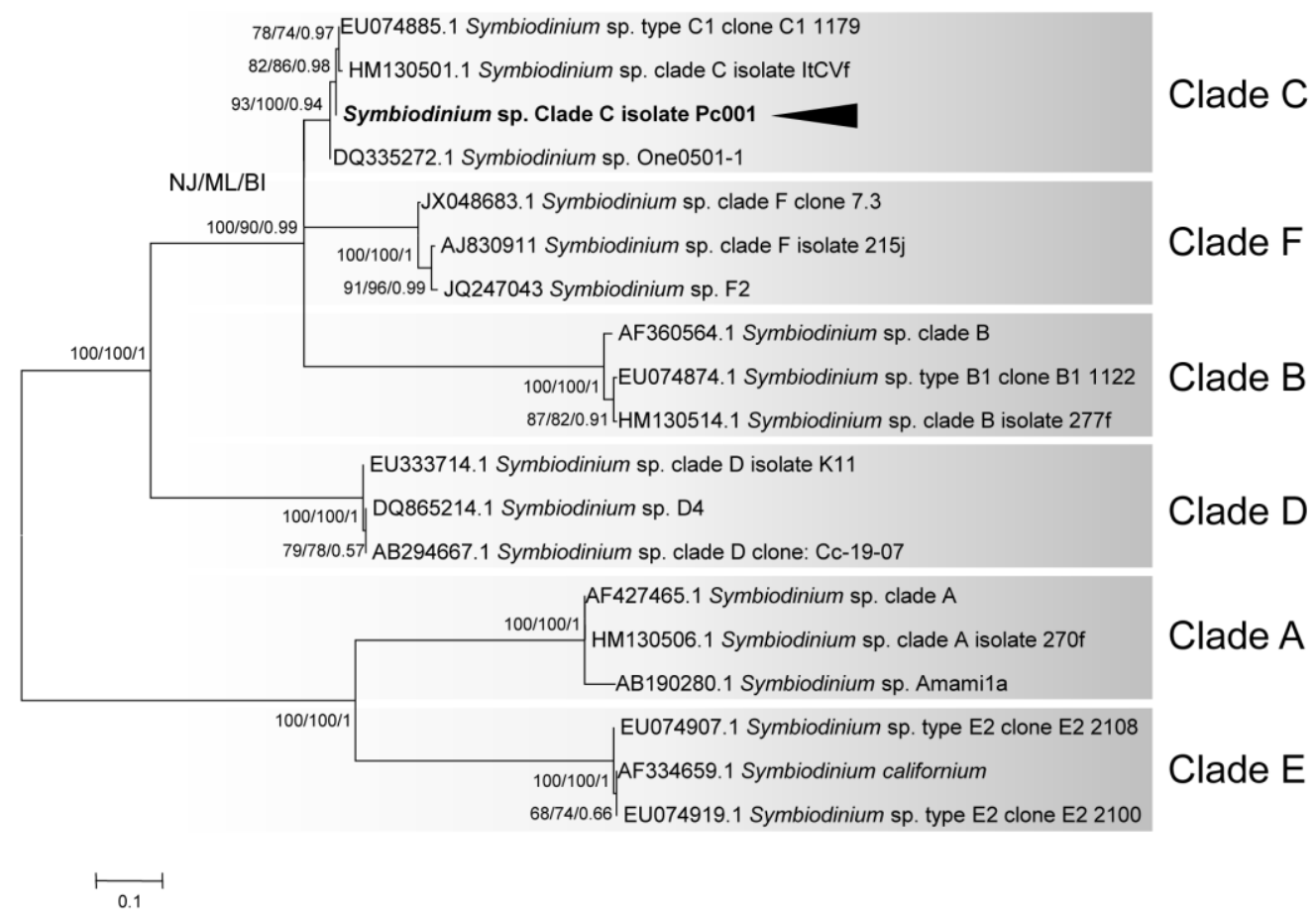

Figure 2. Phylogenetic identification of a Symbiodinium sp. from Palythoa sp. Pc001. Maximum likelihood tree calculated from ITS2-rRNA sequences (268 nucleotide positions) of Symbiodinium clades from various corals under the $\mathrm{K} 2+\mathrm{I}$ model. The $\operatorname{lnL}$ value of this optimal tree is -1592.20 . Support values obtained using different reconstruction approaches are indicated at nodes in the following order: neighbor joining (NJ) maximum likelihood (ML) bayesian inference (BI). Black arrowhead indicates the sequence belonging to the Symbiodinium clade identified in the Palythoa species used for palytoxin extraction. Sequences/species names from previous studies are indicated in regular font with GenBank Accession Numbers. On the right, Symbiodinium clades confirmed to be in symbiosis with various metazoans species (this study and previous studies) designated with shaded boxes. 

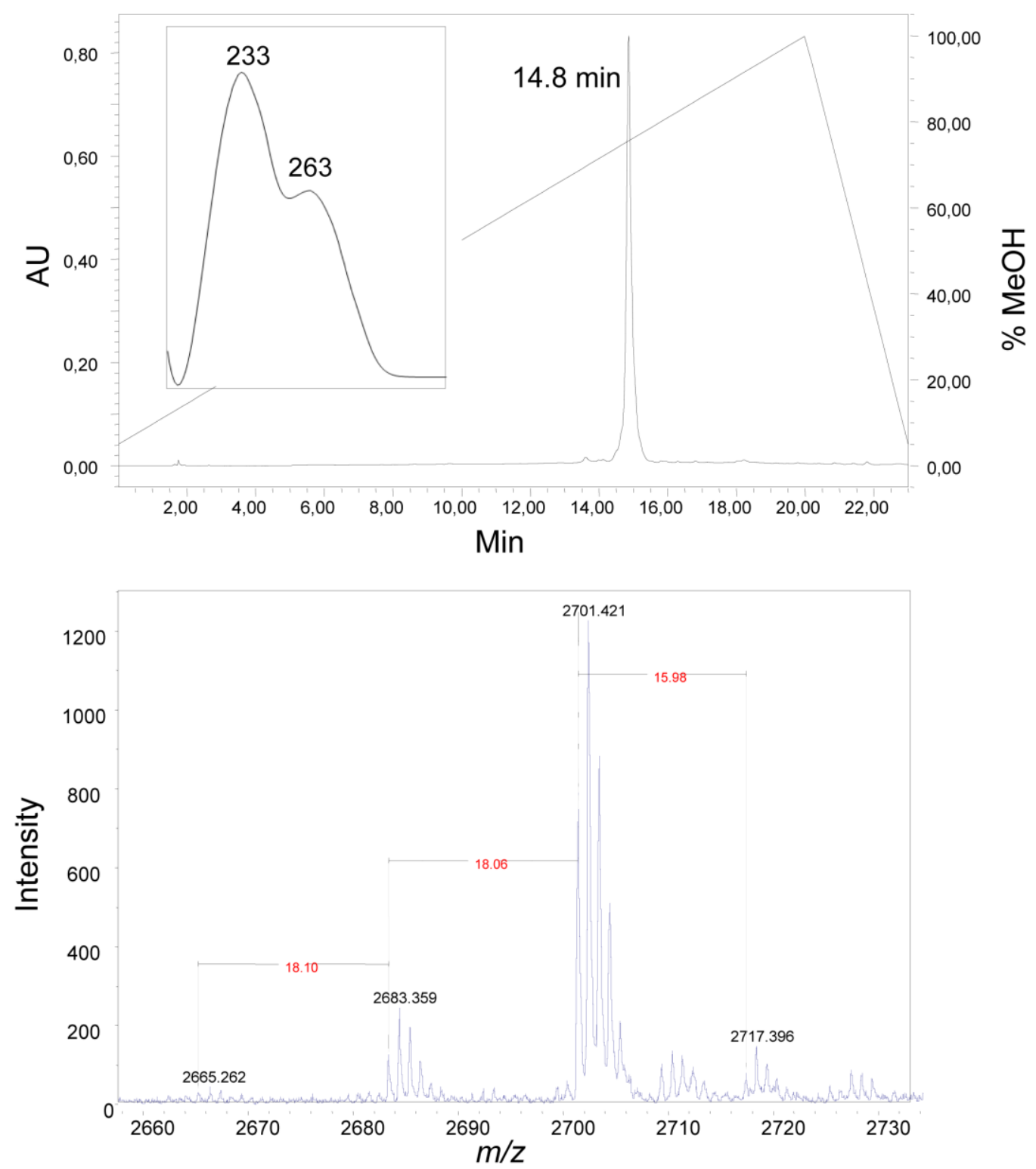

Figure 3. Analysis of palytoxin purified from Palythoa sp. Pc001. A. HPLC profile at 263 $\mathrm{nm}$ of the palytoxin isolated from Palythoa sp. Pc001. The insert graph shows the UV spectrum of the toxin eluted at $14.8 \mathrm{~min}$ in the gradient conditions used (see Methods). B. MALDI-ToF mass spectrum of the palytoxin isolated from Palythoa sp. Pc001. 

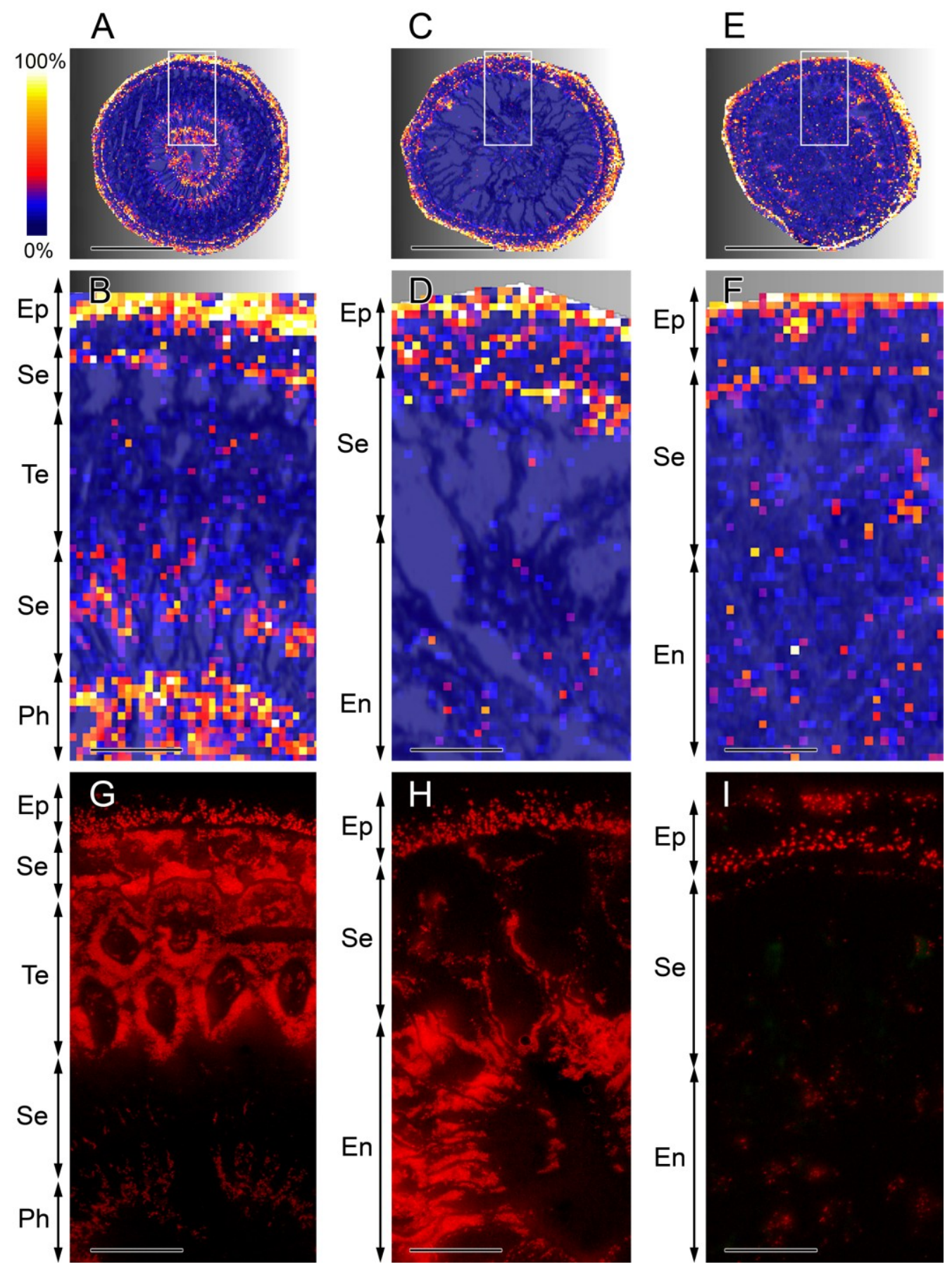

Figure 4. Cross sections of Palythoa sp. Pc001. Sections at the mouth and tentacles (A),

actinopharynx (C) and basal (E) levels demonstrating the location and relative concentrations of palytoxin (PITX) by MALDI-imaging mass spectrometry. Areas delimited by white rectangles are enlarged $(\mathrm{B}, \mathrm{D}, \mathrm{F})$ and compared with images of the same histological regions showing endogenous autofluorescence due to photosynthetic pigments of Symbiodinium cells (G-I). Abbreviations: En, enteron; Ep, epidermis; Ph, pharynx; Se, septa; Te, tentacles. Color scale, highest PITX concentrations (100\%) - no PITX (0\%). Scale bars $=3 \mathrm{~mm}$ (A, C, E), 0.5 $\mathrm{mm}(\mathrm{B}, \mathrm{D}, \mathrm{F}, \mathrm{G}-\mathrm{I})$. 


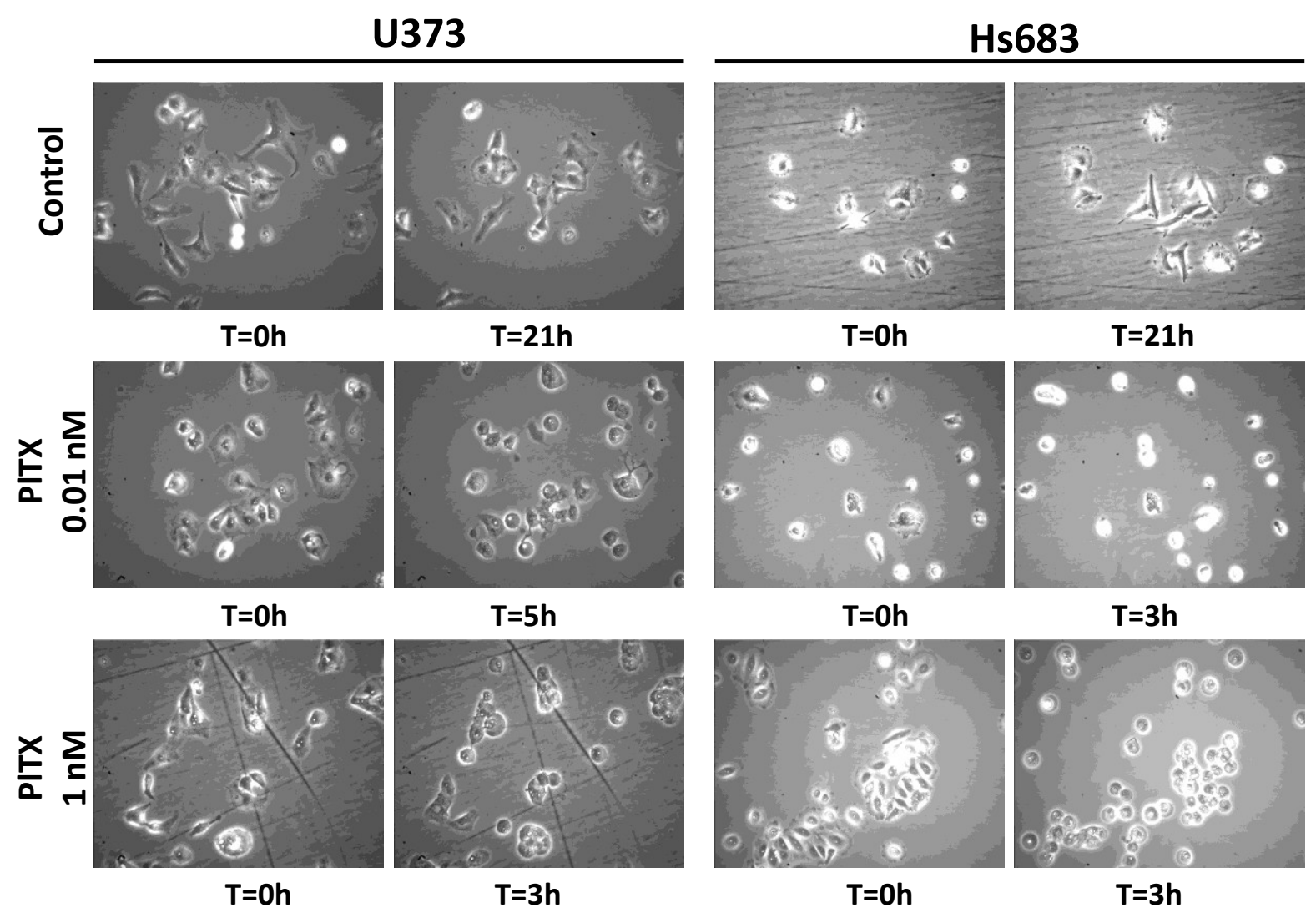

Figure 5. Effect of palytoxin on human cell lines monitored by videomicroscopy. Human U373 (left panel) and Hs683 cell lines (right panel) treated with 0.01 or $1 \mathrm{nM}$ palytoxin. As marked morphological changes of U373 and Hs683 cell lines were observed after 3 to $5 \mathrm{~h}$ of treatment with palytoxin, these timepoints were chosen for their illustrations while growth of the control has been followed and is presented at $21 \mathrm{~h}$. 